\title{
Effect of mid-day meal on nutritional status and haematological profile in school children of Cocody, Abidjan: a case control study
}

\begin{abstract}
We complete a research concerning nutritional status and hemtological profile to determine the impact of school feeding program (canteen) on pupil's health and growth. The protocol involved $139(50 \%)$ boys and $139(50 \%)$ girls asymptomatic subjects aged from $5-12$ years old with an average of $9.10 \pm 1.9$ year old living normal life attending 3 government primary school in Cocody (Abidjan, Côte d'Ivoire). Inclusive criteria were based on those children being healthy. Exclusive criteria were based on students with health complications were not included in that study. All data concerning anthropometric and hemtological parameters were analyzed statistically by using Graph Pad prism version 7 with student $t$ test and Ratio $\mathrm{G}$ test. In this present student, total of 278 pupils were included, about $145(52.16 \%)$ were from SMDM and 133 (47.84\%) from Non SMDM. The prevalence of underweight, Stunting and overweight/obesity were observed in both group. Underweight was respectively $5.26 \%$ in Non SMDM group, $6.26 \%$ in SMDM group at J0 and $0.76 \% \mathrm{~J} 100$ in SMDM group. Stunting was $6.77 \%$ in Non SMDM group, against $0.68 \%$ and $0.76 \%$ respectively at J0 and J100 in SMDM group. Overweight/obesity was 15.04 in Non SMDM group, $15.15 \%$ and $15.37 \%$ respectively at J0 and J 100 in SMDM group. Concerning the prevalence of anaemia, $37.59 \%$ in Non-SMDM and $21.37 \%$ at $\mathrm{J} 0$ and $11.53 \%$ at $\mathrm{J} 100$ in SMDM group.

There was significantly higher prevalence of malnutrition and altered hemtological parameters in non SMDM group as compared to SMDM group. School midday meal improves child nutritional status and hemtological profile. So school canteen has a good effect on children health and nutritional status
\end{abstract}

Keywords: malnutrition, school midday meal, hemtological parameters, anthropometry, cocody (Abidjan)
Volume 5 Issue 2 - 2018

\section{Jacques Koffi Akpole, Mathieu Nahounou Bleyere, Paul Angoué Yapo}

Training and Research Unit of Nature Sciences/ Laboratory of Physiology, Pharmacology and Phytotherapy, Nangui Abrogoua University, Côte d'Ivoire

Correspondence: Mathieu Nahounou Bleyere, Senior Lecturer, Animal Physiology and Physiology of nutrition, Training and Research Unit of Nature Sciences/ Laboratory of Physiology, Pharmacology and Phytotherapy, Nangui Abrogoua University, 02 BP 80I Abidjan 02, Côte d'lvoire, Tel +225-45439-944, +225-78-342-833,

Email chridandre@gmail.com, bleyere@yahoo.fr

Received: February 22, 2018| Published: March 19, 2018
Abbreviations: SMDM, school midday meal; HAZ, height for age $\mathrm{z}$ scores; WAZ, weight for age $\mathrm{z}$ scores; BMI, body mass index; BAZ, body mass index for age $\mathrm{z}$ scores; WHO, world health organization; RBC, red blood cells; $\mathrm{MCV}$, mean corpuscular volume; WBC, white blood cell; MHC, mean haemoglobin concentration; $\mathrm{MCHC}$, mean corpuscular hemoglobin concentration; fl, fentolitre; pg, pictograms; kg, kilograms; cm, centimeter; m, meter; g, gramme; $\mathrm{dl}$, deciliter; ul, microliter; SD, standard deviation; EDTA, ethylene diamine tetra acetate; FAO, food and agriculture organization; SES, socio economical status

\section{Introduction}

Children living in developing countries are confronted by many nutritional challenges. On the one hand, food security, which is threatened with an inadequate supply of nutrients (energy, proteins, fats, minerals and vitamins) with low dietary diversity, is the bed of protein-energy malnutrition and, on the other hand, children are often exposed to a diet approaching occidental countries diet rich in empty calories and fat, most of time with unhealthy dietary practices, lead obviously to over-nutrition and obesity with its corollary of chronic non transmitted disease (diabetes mellitus, cardiovascular pathologies, hypertension). ${ }^{1}$ Problems of macronutrient and micronutrient deficiencies most often associated with low protein foods and problems of overweight are the bed of malnutrition in developing countries. Today, malnutrition with its components namely: protein energy malnutrition, overweight and micronutrients deficiencies constitute a real public health problem in the world. ${ }^{2}$
Most of developing countries, characterized by widespread poverty due to scarce economic resources or an inequitable distribution of wealth accompanied by a fragile health system in society, remain the most affected, particularly countries from South-East Asia and Sub-Saharan Africa. ${ }^{3}$ With 852 million malnourished between 20002002 according to Muller and Krawinkel, ${ }^{3}$ today nearly one billion of individuals, (one in seven) suffer from malnutrition in the world. ${ }^{4}$ Malnutrition remains one of the direct causes of infant mortality worldwide, with over 300,000 deaths per year among children under five years old and indirectly accounting for more than half of all deaths among young children..$^{5-8}$ Malnutrition is a state in which a deficiency or excess of nutrients may increase morbidity or mortality. Several investigators have reported on malnutrition and a risk of under-nutrition such as wasted or stunted condition or overweight in both healthy children and those with specific disorders. ${ }^{9}$ The definition of malnutrition included both under-nutrition (underweight, stunting) and over-nutrition (overweight).

As every developing countries, Cote d'Ivoire doesn't escape from that scourge. In Côte d'Ivoire, the nutritional situation is worrying with regard to the background of the nutritional status of women and children who remain the most vulnerable people in society although the prevalence of malnutrition is decreasing. Malnutrition precisely under nutrition is the cause of nearly $33 \%$ of child and infant mortality. Stunting fell from $34 \%$ in 2006 to $29.8 \%$; Underweight decreased from $20 \%$ to $14.9 \%$, acute malnutrition was $7.5 \%$, and overweight was $22.8 \%$. Despite the decline in prevalence of proteinenergy malnutrition observed these decades, we observe a more and 
more increasing number of individual who are overweighed and obese among the population. Unfortunately, children, do not escape from that situation. So malnutrition st 11 remains a public health problem in Cote d'Ivoire ${ }^{10}$ However, these prevalence is not representative of the whole population. Most of survey carried out by demographic and health surveys (DHS), were focused on children under five years old, neglecting school-aged children whose number in developing countries is abundant. That's why, scarce are real data concerning them. ${ }^{11}$

While, primary school age is a dynamic period of physical growth and mental development of the child. Research indicates that nutritional deficiencies and poor health in primary school age children are among the causes of low school enrolment, high absenteeism, early dropout, learning difficulties and poor performance. ${ }^{12}$ Malnutrition has serious impact on the heath by weakening the immunity system, decreasing the immune reactions, nutrients deficiencies leading to disease particularly anaemia caused by iron deficiency., ${ }^{4,13}$ Also in these school-aged children the installation of malnutrition is insidious and asymptomatic, clinical signs being later to appear. Only biological examinations can detect nutritional disorders before appearance of clinical signs.${ }^{14}$ There are several methods for evaluating a patient's nutritional status, including anthropometric measurements, dietary intake, biochemical parameters, and resting energy expenditure. In addition, the assessment of the nutritional status of a member or community is based on a number of clinical, biological, biophysical and anthropometric indices. ${ }^{15}$ One of the most used method for nutritional status assessment in anthropometry.

Anthropometry is the only tool that is portable, universally applicable, inexpensive and non-invasive. Anthropometry is used to evaluate corpulence, proportions and composition of the human body and even the determination of nutritional and health status, predicting health and life-threatening of individual. ${ }^{16}$ However, anthropometry is only limited for sub-clinical manifestations, so biological evaluation proves to be necessary. There are number of biological parameters which become altered during malnutrition. The privilege of biological evaluation of nutrition is the ability to detect changes long time before the biological and clinical disturbance becomes apparent. ${ }^{17}$ Indeed, analysis of hemtological and biochemical parameters provide real information on the body's cells concentration. Blood analysis of the figurative and nutritive elements of the organism is a key mean to detect any metabolic abnormality and changes in an organism. ${ }^{18}$ It is also the way to observe any variation (quantity and quality) of the rate body's cells. According to previous statement, we must know nutrition and food have an important effect on child growth and health among schoolchildren.

In Côte d'Ivoire, only few studies have been conducted on the impact of school food program on nutritional status and hemtological profile of school age children. Moreover, a recent global increase in both obesity and thinness urges us to evaluate the nutritional status in a general child population. Considering these facts, the purpose of that research is to determine the hemtological profile and nutritional status of school-aged children attending a canteen in comparison to their counterparts who take their lunch outside the canteen in Abidjan. That study is done in order to assess the effect of school midday meal on school children nutritional status. During that study we would determine the nutritional status of school children by anthropometry and haematological parameters by blood analysis in each child. After all we will appreciate the nutritional status of school children according to various groups.

\section{Materials and methods}

\section{Design, setting of the study}

This study was an introspective and observational study and was carried out for 4 months, from March 2016 to June 2016. The study site was government academic primary school situated in Abidjan (Côte d'Ivoire). Data for this study were obtained from a case and control regular survey designed to evaluate the nutritional status and hemtological profile of school children (aged 5-12years) in Cocody (Abidjan) Cote d'Ivoire. Cocody is a district of Abidjan (Abidjan). Abidjan is the economical capital of Cote d'Ivoire capital, the most populated and great town of the country. It occupies a total of 2119 square kilometers with an estimated population of more than 6 million of inhabitant with more than 160 nationalities. ${ }^{19}$

The climate in Abidjan is characterized by tropical humid and dry season with an annual average temperature ranging from $21^{\circ} \mathrm{C}$ and $31^{\circ} \mathrm{C}$. The very hot month is March where temperature can reach sometimes $34^{\circ} \mathrm{C}$. The annual rainfall of this region is estimated at $1152,2 \mathrm{~mm}$, with approximately $90 \%$ of rain falls between April and October. The dry season normally begins in November and ends in March.

The city is bordered by the Atlantic Ocean and Ebrie Lagoon that makes Abidjan the pearl of lagoons. Abidjan houses the most important fishing, commercial port and harbor of West Africa and most of the main factories of the country. Abidjan is a cosmopolitan urban area with people from different regions, belonging to different ethnic group. Although a number of ethnic groups are represented in Abidjan, Ebrie Ethnic groups are the native of the area. The major language spoken in this area is French, although slang language (language of street) is also well spoken by everyone. That kind of language is a mix of different patois of the country with French. French is widely spoken in schools, offices and markets. Abidjan is acclaimed as Cote d'Ivoire "Food Basket", because of its diverse agricultural resources. Most of the food that comes from others regions of the country converge on Abidjan. For this regard, trading and agricultural are the mains activities in the area. Concerning activities, most of people are civil servant and business people. Apart from civil service, others people are mainly self-employed in companies, petty trading, private employed, fishermen, workers and wide proportion are unemployed person. Moreover, Abidjan knows the phenomenon of immigration. Rural and economical immigration from neighborhood countries is widespread involving working age men with a growing number of women and children, which lead to overpopulation, unemployment (youth unemployment), illiteracy, poverty and social insecurity.

The major staple foods are Attiéké (semolina of cassava (Manihot esculenta), yam (Dioscorea alata), plantain (Musa sinensis and Musa paradisiaca), Maize (Zea mais), bread, season fruits and vegetable are found abundantly on the market. Beef, fish, chicken, snail are the main sources of protein. However, some people in Abidjan didn't have normal diet and are still struggling to find their daily bread. More than $5 \%$ of the inhabitants do not spend more than one dollars US per day. High inflation, lowering of the population's purchasing power that leaded to increasing the level of poverty following the socio political instabilities the country faced from 2002 to 2012, contributed on a long term basis to the deterioration of nutritional status of the population. Cocody is the most expensive district in Abidjan, because it houses the best universities and high schools, primary schools of the country. Also the mains infrastructures such road, hospital, and banks 
are located in this area. In Cocody, most of foreign embassies and political party's headquarters are located. That's why Cocody claims to be the most peaceful, protected and safety residential district of Abidjan.

\section{Sample}

The study involved 3 publics school where school midday was given to the pupil. A total number of 500 children were selected to allow for refusals and complete data. Apparently 278 healthy children aged from 5 to 14 years where included for this research. A number of 222 children didn't give their agreement to be included. Out of 278 pupils, 178 who received regularly School Midday Meal constituted our study subjects (SMDM group) and 133 pupils who didn't not received School Midday Meals were our comparison or control group (Non SMDM group). Three primaries schools were visited (Kouadio Assahoré, Hoba Hélène and Rosiers primary school) from March to June 2016. The input variables of the study comprised the Midday meals and the outcome variables included anthropometric measurement and blood hemtological estimation. The first stage included the selection of schools and the second stage consisted of random sampling of boys and girls of each age category from the total enrolment in their school.

Only 278 children (139 boys against 139 girls) were included as pupils that filled out the questionnaire. Participating school were selected according to the fact that those school follow a school feeding program in the area of Cocody. In all the selected schools children within the age 5-12 years were eligible to participate in the study and were measured. Pupil birth's certificates were used to establish ages of participants in the study group. The selection of these three schools in Abidjan was possible with the help of department of education of Cocody1 (Abidjan). In Côte d'Ivoire, public schools cater low Socio Economical Status (SES) urban and rural children while High SES is educated in private school. School administration of the three schools gave their agreement to do that study. For each school, a list of all classes (grade one to grade 6) was obtained from the headmaster. Children who were unwell or didn't have any written parental consent were excluded from the study.

A total of 278 children (139 boys; 139 girls) were selected randomly from three government schools. The sample size estimation was done using previous cross-sectional studies on growth in the same area. Let us remember that school midday meal (SMDM) program is implemented by government in schools in order to help school children who live far away from the school to benefit a dieted meal per day and to fight against hunger at school. Major regions of both the cities were screened, and a list of schools was prepared which included government schools. Out of them, a total of 3 schools were included randomly. All the schools provided their consent for conducting the study. Participants with any chronic ailment, congenital diseases or any major surgery or taking any medications were excluded from the study. Inclusion criteria comprised apparently healthy children in the age group of 5-14 years. Out of those who satisfied the inclusion criteria, a total of 278 pupils (stratified by gender: girls, $n=139$; boys, $\mathrm{n}=139$ ) were chosen from three public schools. The selection of participants was done using computerized random number generation.

\section{Data collection}

\section{Anthropometry}

Data collection's activity was planned to avoid biased measurements. We started collecting data during the first two weeks of a new school year or immediately after a major holiday. All the instruments we used, were standardized before starting measurements. Also scales were zero calibrated each day before the measurements. Height and weight were measured without shoes, the pupils wore the school uniforms and were in fasting condition. Height and weight were measured according to the standard procedures of World Health Organization.$^{16}$ Weight was measured to the nearest $0.1 \mathrm{~kg}$ with electronic bathroom scale (Béryl China). Weight was recorded twice and the mean value was recorded. If there was an exceeded difference of $0.2 \mathrm{~kg}$ between two measures, the child was sent to rest for 2 minutes before weighting again. After one hour of measurement the scale was calibrated immediately if mistake was found in the weight of the child. Individual height was measured with a wooden stadiometer placed on a flat surface twice. The subject stood on the basal part of the device by putting one's feet together without shoes. The shoulders, the buttocks and the heels were stuck on the vertical measuring board. Children standing up with eyes in the Franckfort horizontal plane, the height was measured to the nearest of $0.1 \mathrm{~cm}$. However when the difference between two measures was higher than $0.3 \mathrm{~cm}$ the exercise was taken again with more carefully attention. Nutritional indices or $Z$ score of Body Mass Index for Age (BAZ), Weight for Age (WAZ) and Height for Age (HAZ) were used to assess different nutritional status such as thinness/ overweight/obesity, underweight and stunting respectively, using the new reference values for school boys and girls based on the 2007 WHO Growth Reference for children 5-19 years. ${ }^{20}$ We used WHO AntroPlus software 1.0.4 version for calculating nutritional indices and Excel 2013 software for data recording and processing.

\section{Hemtological estimations}

In all pupils ( $\mathrm{n}=278), 5 \mathrm{ml}$ of venous blood was collected by venipuncture using a fixed hypodermic needle under aseptic conditions, after cleaning the venipuncture site with $90 \%$ alcohol. The blood specimen was decanted into a sample tube containing ethylene diamine tetra acetate (EDTA) and gently mixed to avoid clotting. Then the entire sample was carried to laboratory to be analyzed by using an automated blood analyzer model Sysmex KN 21.

Hemoglobin concentrations were measured by cyanmethemoglobin method (differential lysis with Beckman Coulter principle; Coefficient of variance $=1.5 \%$ ). The others blood parameters such Leucocytes, lymphocytes, platelets were determined by the automate blood analyzer.

Erythrocytes indices such Mean Hemoglobin Concentration (MHC), hematocrit, Mean Corpuscular Volume, Mean Corpuscular Hemoglobin Concentration (MCHC) were determined automatically by the Automate Analyzer KN 21.

The normal range for hemoglobin concentrations in children is $11.5 \mathrm{~g} / \mathrm{dl}$ and more for age 5-11 years, and $12 \mathrm{~g} / \mathrm{dl}$ for adolescent or higher for age 12-14 years. Hemoglobin concentrations between 11.0$11.4 \mathrm{~g} / \mathrm{dl}$ (5-11 years) and 11.0-11.9 g/dl (12-14 years) represent the cutoff values for mild anemia, hemoglobin concentration between 8.0 and $10.9 \mathrm{~g} / \mathrm{dl}$ (5-11 years and 12-14 years) represents the cutoff values for moderate anemia and hemoglobin level below $8.0 \mathrm{~g} / \mathrm{dl}(\mathrm{Hb}<8.0 \mathrm{~g} /$ dl) represents the cutoff values for severe anemia. ${ }^{21}$

\section{Sociodemographic variables}

For each of the sampled classes, demographic information of 
all officially enrolled students was obtained before data collection. Those information included gender, date of birth, residential address and parental education. Parental education's level was based on the parent with highest total years of schooling or not, income's level was based on the approximate income estimate of parent's salary. The study instrument was a structured questionnaire; designed in French. The questionnaire was tested for reliability and accuracy. It included questions on family and socio cultural environment including parental working status, number of siblings, number of child's bedroom, and the size of the family. The students were interviewed in the presence of their class teacher and each pupil was asked regarding whatever his/her mother works or is a housewife, how many older/younger siblings he/she has? How many person were living in his bedroom? Quality control measurement and good practices included training of data collection team, pre testing of processes and materials field monitoring of data collection were checked before the beginning of the study. Verbal consent for the child to participate in the study was taken from class teachers and parents.

\section{Statistical analysis}

For easy sorting, the data obtained were entered into Microsoft Excel 2013, and different parameter related to subjects analyzed using GraphPad Prism software 7.00 version for comparison of mean value and the like hood Ratio software R.2.10.1 version for comparison of proportion. Descriptive characteristics (mean and standard deviations) were computed for anthropometric and haematological measures in boys and girls belonging to SMDM receiving and non-SMDM receiving group. Student's t-test a non-parametric unpaired test was used to compare the mean values of nutritional and hemtological parameters between SMDM receiving and non-SMDM receiving children with Graph Pad Prism 7.00 version software. Likelihood Ratio Statistic G-test $\mathrm{x}$-squared was used to estimate the proportion of stunting, underweight, overweight, and anemia among SMDM receiving and Non-SMDM receiving children with Ratio R 2.10.1 version software. The analysis was stratified for gender and the statistical significance level was $\mathrm{p}<0.05$.

\section{Ethical approval and consent}

The purpose of the study and its importance was explained to the administrative authorities, directors and teachers of schools along with children and their parents. An informed written consent was obtained

Table I General characteristics of study population stratified by gender

\begin{tabular}{|c|c|c|c|c|c|c|c|c|c|c|c|}
\hline \multirow[t]{2}{*}{ Variables } & \multicolumn{3}{|c|}{ Non SMDM } & \multicolumn{3}{|l|}{ SMDM } & \multirow[t]{2}{*}{ PI } & \multirow[t]{2}{*}{$\mathbf{P 2}$} & \multirow[t]{2}{*}{ P3 } & \multirow[t]{2}{*}{ P4 } & \multirow[t]{2}{*}{ P5 } \\
\hline & $\begin{array}{l}\text { Total } \\
\text { (I33) }\end{array}$ & $\begin{array}{l}\text { Male } \\
(57)\end{array}$ & $\begin{array}{l}\text { Female } \\
\text { (76) }\end{array}$ & $\begin{array}{l}\text { Total } \\
(145)\end{array}$ & $\begin{array}{l}\text { Male } \\
(82)\end{array}$ & Female (63) & & & & & \\
\hline Age (years) & $9.5 I \pm 2.12$ & $9.94 \pm 2.03$ & $9.2 \pm 2.13$ & $8.70 \pm 1.68$ & $8.78 \pm 1.74$ & $8.59 \pm 1.59$ & $0.003 *$ & 0.05 & 0.55 & $0.003 *$ & 0.23 \\
\hline $5-9(186)$ & $76(57.14)$ & $30(52.63)$ & $46(60.63)$ & $110(75.86)$ & 59(7I.95) & $5 I(80.95)$ & 0.1 & 0.45 & 0.46 & 0.08 & 0.08 \\
\hline $10-14(92)$ & $57(42.86)$ & $27(47.37)$ & $30(39.47)$ & $35(24.14)$ & $23(28.05)$ & $12(19.05)$ & 0.02 & 0.39 & 0.18 & 0.02 & 0.006 \\
\hline \multicolumn{12}{|c|}{ Parents demographics } \\
\hline In couple (\%) & I I 7(87.97) & $50(87.72)$ & $67(88.16)$ & I I4(78.62) & 67(8I.7I) & $47(74.60)$ & 0.46 & 0.97 & 0.56 & 0.64 & 0.28 \\
\hline Single (\%) & $16(12.03)$ & $7(12.28)$ & $9(11.84)$ & $31(21.38)$ & I5(I8.29) & $16(25.40)$ & 0.1 & 0.92 & 0.28 & 0.27 & 0.02 \\
\hline $\begin{array}{l}\text { Household } \\
\text { size }\end{array}$ & $7.03 \pm 2.68$ & $7.03 \pm 1.42$ & $7.50 \pm 3.32$ & $6.90 \pm 1.62$ & $6.80 \pm 1.65$ & $7.03 \pm 1.57$ & 0.13 & 0.76 & 0.45 & 0.19 & 0.82 \\
\hline$<5$ & $8(6.02)$ & $2(3.51)$ & 6(7.89) & $5(3.45)$ & $4(4.88)$ & I(I.59) & 0.4 & 0.18 & 0.18 & 0.63 & 0.003 \\
\hline$>5$ & $125(93.98)$ & $55(96.49)$ & $70(92.11)$ & $140(96.55)$ & $78(95.12)$ & $62(98.4 I)$ & 0.85 & 0.74 & 0.81 & 0.92 & 0.64 \\
\hline
\end{tabular}

from the school authorities and parents, and an assent from children participating in the study was also obtained. If the parents were illiterate, the information was read out to them in the local language by a literate member of the family and if they agreed to participate in the study, then their thumbprint or signature was taken. Some children and parents who were approached agreed to participate in the study, others refused to take part in the study. Children and parents, willing to take part in the study were interviewed to fill a screening questionnaire; the children also underwent a clinical examination at the baseline, so as to ensure that they did not have any major illness history in the past that might affect their health status. Ethical approval was granted by the Ethics Committee of Nangui Abrogoua University.

Children were classified into 2 groups according to their participation to School Midday Meal program or not. The children from government school receiving SMDM (target group) belonged to all Socio economic Status. The Non- SMDM children were selected as healthy control group to make a comparative analysis of nutritional status in SMDM children.

\section{General characteristics of the study population stratified by gender}

From the analysis of that study, Table 1 presents the general social and economic profile of the study population. According to the finding, a total of 278 children were involved in that study with 139 (50\%) girls and 139 (50\%) boys. In addition 186 (66.91\%) children belonged to 5-9 years range and $92(33.09 \%)$ were aged from 10 14 years. The children were grouped together in two groups: SMDM groups and Non SMDM. SMDM group concerned 145 children and Non SMDM group was concerned by 133 children. The pupils from the control group (Non SMDM) were statistically older than pupils from the target group (SMDM). The comparison of the mean age showed a significant difference between Non SMDM receiving group taken as control group and SMDM receiving group our target group $(9.51 \pm 2.12$ vs $8.70 \pm 1.68$ years $\mathrm{p}=0.003)$. There was significant difference between control group and subjects in what concerning the age, children who received School Midday Meals were younger than those from Non SMDM receiving group. Concerning marital status of parents in Non- SMDM receiving group, $87.97 \%$ of parent was in couple and $12.03 \%$ was single. In SMDM receiving group, $78.62 \%$ of parent was in couple and $21.38 \%$ were single without any statistically difference $(\mathrm{p}>0.05)$. 
Table continued

\begin{tabular}{|c|c|c|c|c|c|c|c|c|c|c|c|}
\hline Variables & Non SMD & & & SMDM & & & $\mathbf{P I}$ & $\mathbf{P 2}$ & P3 & P4 & P5 \\
\hline \multicolumn{12}{|c|}{ Mother's education level } \\
\hline $\begin{array}{l}\text { Post- } \\
\text { secondary }\end{array}$ & 12(9.02) & $4(7.02)$ & $8(10.53)$ & $3 I(2 I .38)$ & $20(24.39)$ & II(I7.46) & 0.02 & 0.4 & 0.28 & 0.001 & 0.18 \\
\hline Secondary & $23(17.29)$ & $10(14.54)$ & $13(17.10)$ & $84(57.93)$ & $48(58.54)$ & $36(57.14)$ & $1.48 . e^{-6}$ & 0.64 & 0.89 & 9.95. $e^{-8}$ & $1.81 . \mathrm{e}^{-6}$ \\
\hline Primary & $50(37.59)$ & $22(38.60)$ & $28(36.84)$ & $22(15.17)$ & $\mathrm{II}(\mid 3.4 \mathrm{I})$ & $1 \mathrm{I}(17.46)$ & 0.001 & 0.83 & 0.46 & 0.0003 & 0.007 \\
\hline None & $48(36.09)$ & $2 \mathrm{I}(36.84)$ & $27(35.53)$ & $8(5.52)$ & $3(3.66)$ & $5(7.94)$ & $5.41 \mathrm{e}^{-7}$ & 0.87 & 0.2 & 1.92. $\mathrm{e}^{-8}$ & $1.35 \mathrm{e}^{-5}$ \\
\hline \multicolumn{12}{|c|}{ Mother's activity } \\
\hline Civil servant & $9(6.77)$ & $3(5.26)$ & $6(7.89)$ & $63(43.45)$ & $35(42.68)$ & $28(44.44)$ & $4.54 \mathrm{e}^{-8}$ & 0.46 & 0.85 & $7.93 e^{-9}$ & $1.11 \mathrm{e}^{-7}$ \\
\hline $\begin{array}{l}\text { Private } \\
\text { servant }\end{array}$ & $27(20.30)$ & $4(7.02)$ & $23(30.26)$ & $53(36.55)$ & $33(40.24)$ & $20(31.75)$ & 0.02 & $7.77 e^{-5}$ & 0.31 & $3.78 \mathrm{e}^{-7}$ & 0.85 \\
\hline Self employed & $25(18.80)$ & $18(31.58)$ & $7(9.22)$ & $13(8.97)$ & $4(4.88)$ & $9(14.29)$ & 0.05 & 0.0003 & 0.02 & $2.96 \cdot \mathrm{e}^{-6}$ & 0.29 \\
\hline Unemployed & $72(54.13)$ & $32(56.14)$ & $40(52.63)$ & $16(11.03)$ & $10(12.20)$ & $6(9.52)$ & 2.48. $e^{-8}$ & 0.73 & 0.56 & $3.14 \mathrm{e}^{-8}$ & $9.52 e^{-9}$ \\
\hline \multicolumn{12}{|c|}{ Father's education level } \\
\hline $\begin{array}{l}\text { Post- } \\
\text { secondary }\end{array}$ & $27(20.30)$ & II (19.30) & $16(21.05)$ & $92(63.45)$ & $53(64.63)$ & $39(61.90)$ & I.35. $e^{-6}$ & 0.78 & 0.8 & $3.71 . e^{-8}$ & 4.54. $\mathrm{e}^{-6}$ \\
\hline Secondary & $71(53.38)$ & $33(57.89)$ & $38(50)$ & $46(31.72)$ & $26(3 I .7 I)$ & $20(31.75)$ & 0.01 & 0.44 & 0.99 & 0.005 & 0.04 \\
\hline Primary & $25(18.80)$ & $10(17.54)$ & $15(19.74)$ & $7(4.83)$ & $3(3.66)$ & $4(6.35)$ & 0.002 & 0.71 & 0.39 & 0.001 & 0.007 \\
\hline None & $10(7.52)$ & $3(5.26)$ & $7(9.21)$ & $0(0)$ & $0(0)$ & $0(0)$ & 0.001 & 0.29 & - & 0.006 & 0.0003 \\
\hline \multicolumn{12}{|c|}{ Father's activity } \\
\hline Civil servant & $19(14.29)$ & $4(7.02)$ & $15(17.74)$ & $65(44.83)$ & $34(41.46)$ & $3 I(49.21)$ & 4.72. $e^{-5}$ & 0.02 & 0.41 & 1.92. $\mathrm{e}^{-7}$ & 8.73. $e^{-5}$ \\
\hline $\begin{array}{l}\text { Private } \\
\text { servant }\end{array}$ & $64(48.12)$ & $29(50.88)$ & $35(46.05)$ & $72(49.66)$ & $44(53.66)$ & $28(44.44)$ & 0.87 & 0.62 & 0.35 & 0.78 & 0.86 \\
\hline Self employed & $48(36.09)$ & $24(42.11)$ & $24(31.58)$ & $8(5.52)$ & $4(4.88)$ & $4(6.35)$ & $5.41 \mathrm{e}^{-7}$ & 0.21 & 0.66 & 6.09. $e^{-9}$ & $1.87 . e^{-5}$ \\
\hline Unemployed & $2(1.50)$ & $0(0)$ & $2(2.63)$ & $0(0)$ & $0(0)$ & $0(0)$ & 0.14 & 0.05 & - & - & 0.05 \\
\hline
\end{tabular}

SMDM, school midday meal; PI, comparison between total in Non SMDM and SMDM; P2, comparison between male in Non SMDM and male SMDM;

P3, comparison between male in Non SMDM and Female in Non-SMDM; P4, comparison between female in Non SMDM and female SMDM group; P5, comparison between male and female in SMDM group

Concerning the household size, $7.89 \%$ of children lived in a family with less than five individuals, $93.98 \%$ in Non SMDM group and $96.55 \%$ in SMDM group belonged to family with more than five individual. Concerning mother's education level, $9.02 \%$ in Non SMDM receiving group had post-secondary level against $21.38 \%$ in SMDM receiving group $(\mathrm{p}=0.02)$. Moreover $36.09 \%$ of mother in control group were statistically illiterate comparatively to target group (SMDM group) with a percentage of $6.52 \%\left(\mathrm{p}=5.41 . \mathrm{e}^{-7}\right)$. In what concern mother's activity, $54.13 \%$ were statistically unemployed in Non SMDM receiving against $11.03 \%$ in SMDM receiving group $(\mathrm{p}<0.05)$. In another way $43.45 \%$ of mother in SMDM group were civil servant in relation to Non SMDM group with $6.77 \%$ of civil servant with a statistically significance difference $(p<0.05)$. Concerning father's education, $63.45 \%$ children belonging to SMDM group had father with a post-secondary level against $20.30 \%$ in Non SMDM group $(\mathrm{p}<0.05)$. In SMDM group, none case of illiteracy had been found compared to SMDM group with $7.52 \%$ of illiteracy $(p=0.001)$.

Most of father in Non SMDM group were in secondary level (53.38\%) against $31.72 \%$ in SMDM group, $18.80 \%$ of father in SMDM group against $4.83 \%$ in SMDM group were primary level $(\mathrm{p}=0.002)$. Concerning father activity, $44.83 \%$ in SMDM group against $14.29 \%$ in Non SMDM group were civil servant. More than $36.09 \%$ of parents in control group against $5.52 \%$ in target group (SMDM group) were self-employed or belonged working class.

\section{Diet}

Target group (SMDM receiving) children received Midday meal once in their school during the recess time per day. The average menu comprised rice (Oryza Sativa), potatoes (Ipomea Batats), bread, and spaghetti and cassava semolina (Manihot exculenta) nationally called Attiéké, as carbohydrates. Proteins provided from vegetables, meat, chicken, fishes and oil prepared. Recipes were various such as Attiéké with fried fish or chickhen, vegetable sauce with rice called N'troh, potatoes stew with meat, Fatty rice called Tchep guen. SMDM (School Midday Meal) program is designed to provide $450 \mathrm{kcal}$ of energy and $12 \mathrm{~g}$ of proteins for primary classes (grade 1-5) while $700 \mathrm{kcal}$ of energy and $20 \mathrm{~g}$ of proteins for upper primary classes (grade 6-8)..$^{22,23}$

A weekly menu for the school was pre-decided and accordingly the recipes served throughout the week at home. All children reported the quantity of the SMDM recipes consumed through .the midday meal provided to them in their school, during their 24 hours of diet recall.

\section{Results}

\section{Changes of anthropometrical and haematological parameters in study population}

According to Table 2A, the mean value of Height for Age (HAZ), was significantly lower in Non SMDM group (control) $(-0.18 \pm 1.50$ 
$\mathrm{SD})$ as compared to SMDM group (target group) $(0.17 \pm 1.09 \mathrm{SD})$ at the first survey $(\mathrm{p} 1=0.02)$. But no significant difference was observed at the second survey J100) between control group (Non SMDM receiving group) and target group (SMDM receiving group) ( $\mathrm{p} 2=0.06)$. Concerning Body Mass Index for Age (BAZ), the mean values were respectively $(-0.22 \pm 1.14 \mathrm{SD})$ and $(-0.13 \pm 1.29 \mathrm{SD})$ at J0 in Non SMDM receiving group and SMDM receiving group. At the second visit (J100), BAZ mean value was significantly higher in SMDM group $(0.16 \pm 1.11 \mathrm{SD})$ in comparison with Non SMDM group $(-0.22 \pm 1.14 \mathrm{SD})$ and $\mathrm{SMDM}$ group $(-0.13 \pm 1.29 \mathrm{SD})$ at the first survey $(\mathrm{J} 0)\left(\mathrm{p}^{2}=0.006 ; \mathrm{p}^{3}=0.04\right)$. Furthermore the children belonging to control group (Non SMDM group) were significantly older than those of target group (SMDM group) (114.06 \pm 25.53 vs $104.41 \pm 20.23$ months.
Table 2B showed the mean values of haematological parameters, all the values were normal comparing to the reference values in control (Non SMDM) and target (SMDM group) in the red corpuscle except the mean value of $\mathrm{MCV}$ that was under the normal value (71.65 \pm 7.32 fl). However, children from target group (SMDM group) showed high level red blood cells at first survey $\mathrm{J} 0(4.49 \pm 0.46 \mathrm{x} 106 / \mu 1)$ and second survey J100 $(4.45 \pm 0.12 \times 106 / \mu 1)$ in comparison to control (Non SMDM) group $(4.24 \pm 0.29 \times 106 / \mu 1)$. Concerning the white corpuscle, the mean value of white blood cell (WBC) and neutrophils $(3551.09 \pm 683.18 / \mu \mathrm{l})$ were significantly higher in Non SMDM group $(6310 \pm 870 / \mu 1)$ as compared to SMDM group respectively at J0 and $\mathrm{J} 100(5044 \pm 1640 / \mu \mathrm{l} ; 4370 \pm 660 / \mu \mathrm{l})$. Concerning the other parameters SMDM group showed high rate as compared to the Non SMDM group.

Table 2A Mean values of anthropometrical parameters in the study population

\begin{tabular}{|c|c|c|c|c|c|c|}
\hline Variable & Non SMDM - I33 & & & PI & $\mathbf{P 2}$ & P3 \\
\hline & & J 0 (I45) & J $100(130)$ & & & \\
\hline AGE (Month) & $114.06 \pm 25.53$ & $|04.4| \pm 20.23$ & $104.02 \pm 19.69$ & 0.001 & 0.001 & 0.85 \\
\hline Weight (Kg) & $29.79 \pm 7.88$ & $29.05 \pm 8.25$ & $30.13 \pm 9.14$ & 0.468 & 0.73 & 0.3 \\
\hline Height (Cm) & $|33.72 \pm||.6|$ & $131.91 \pm 11.10$ & $132.93 \pm 1 \mid .14$ & 0.17 & 0.58 & 0.43 \\
\hline BMI $\left(\mathrm{Kg} / \mathrm{m}^{2}\right)$ & $16.41 \pm 5.80$ & $16.34 \pm 2.80$ & $16.69 \pm 2.81$ & 0.82 & 0.35 & 0.27 \\
\hline WAZ (SD) & $0.16 \pm 1.21$ & $0.04 \pm 1.19$ & $0.18 \pm 1.14$ & 0.52 & 0.89 & 0.41 \\
\hline HAZ (SD) & $-0.18 \pm 1.50$ & $0.17 \pm 1.09$ & $0.12 \pm 1.09$ & 0.02 & 0.06 & 0.73 \\
\hline BAZ (SD) & $-0.22 \pm 1.14$ & $-0.13 \pm 1.29$ & $0.16 \pm 1.11$ & 0.55 & 0.006 & 0.04 \\
\hline
\end{tabular}

SMDM, school midday meal; BMI, body mass index;WAZ, weight for age $Z$ score; HAZ, height for age $Z$ score; $B A Z$, BMI for age $Z$ score; J0, first survey; JI00, second survey; PI, comparison between Non SMDM receiving group and SMDM receiving group at J0; P2, comparison between Non SMDM receiving group and SMDM receiving group JI00; P3, comparison between SMDM receiving group at J0 and SMDM receiving group at J I00; SD, Standard Deviation

Table 2B Mean values of hematological parameters in the study population

\begin{tabular}{|c|c|c|c|c|c|c|}
\hline Variables & Non SMDM(133) & SMDM & & $\mathbf{P I}$ & $\mathbf{P 2}$ & $\mathbf{P 3}$ \\
\hline & & $\mathrm{JO}(145)$ & J $100(130)$ & & & \\
\hline RBC $(106 / \mu l)$ & $4.24 \pm 0.29$ & $4.49 \pm 0.46$ & $4.45 \pm 0.12$ & $<0.0001$ & $<0.0001$ & 0.29 \\
\hline Hemoglobin $(g / d l)$ & $11.89 \pm 1.04$ & $12.14 \pm 1.18$ & $12.08 \pm 0.58$ & 0.58 & 0.06 & 0.07 \\
\hline Hematocrit (\%) & $36.59 \pm 3.00$ & $38.08 \pm 2.11$ & $38.24 \pm 2.24$ & $<0.000$ I & $<0.0001$ & 0.53 \\
\hline MCV (fl) & $83.86 \pm 4.04$ & $71.65 \pm 7.32$ & $87.70 \pm 2.38$ & $<0.0001$ & $<0.0001$ & $<0.0001$ \\
\hline $\mathrm{MCH}(\mathrm{pg})$ & $27.67 \pm 1.86$ & $27.28 \pm 1.94$ & $28.82 \pm 1.35$ & 0.09 & $<0.0001$ & $<0.0001$ \\
\hline $\mathrm{MCHC}(\mathrm{g} / \mathrm{dl})$ & $32.50 \pm 1.72$ & $32.16 \pm 3.44$ & $32.49 \pm 1.35$ & 0.28 & 0.89 & 0.31 \\
\hline Platelets $(103 / \mu \mathrm{l})$ & $239.2 \pm 24.43$ & $285.2 \pm 71.91$ & $242.93 \pm 34.03$ & $<0.0001$ & 0.31 & $<0.0001$ \\
\hline WBC $(/ \mu \mathrm{l})$ & $6310 \pm 870$ & $5044 \pm 1640$ & $4370 \pm 660$ & $<0.0001$ & $<0.0001$ & $<0.0001$ \\
\hline P. Neutrophils $(/ \mu \mathrm{l})$ & $3551.09 \pm 683.18$ & $18 \mid 3.93 \pm 1263.78$ & $2364.44 \pm 416.1$ & $<0.0001$ & $<0.0001$ & $<0.0001$ \\
\hline 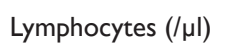 & $2489.26 \pm 444.85$ & $2795.29 \pm 1047.45$ & $1793.43 \pm 375.34$ & $<0.002$ & $<0.001$ & $<0.0001$ \\
\hline Monocytes $(/ \mu \mathrm{l})$ & $243.50 \pm 18.56$ & $313.55 \pm 181.99$ & $213.59 \pm 93.96$ & $<0.0001$ & $<0.01$ & $<0.0001$ \\
\hline
\end{tabular}

SMDM, school midday meal; RBC, red blood cells; MCV, mean corpuscular volume;WBC, white blood cell; MHC, mean hemoglobin concentration; MCHC, mean corpuscular hemoglobin concentration; P, polynuclear; J0, first survey; JI00, second survey; PI, comparison between Non SMDM receiving group and SMDM at J0; P2, comparison between Non SMDM receiving group and SMDM at JI00; P3, comparison between SMDM receiving group at J0 and SMDM receiving at JI00 


\section{Variation of anthropometrical and haematological indices in study population according to sex}

The finding registered in Table 3, presented the general mean values of anthropometrical and haematological parameters in male population. From those findings, Non SMDM children were older than SMDM group with statistical difference (119.28 \pm 24.42 versus
$105.43 \pm 20.98$ month; $\mathrm{p}=0.0005)$.

Concerning height for age $\mathrm{z}$ score (HAZ) value, children from SMDM who received Midday Meal had higher mean value at $\mathrm{J} 0$ and $\mathrm{J} 100$ in comparison to Non SMDM receiving group $(0.11 \pm 1.13 \mathrm{SD}$; $-0.05 \pm 1.14$ SD vs $-0.65 \pm 1.23 \mathrm{SD})$.

Table 3 Means values of anthropometrical and hematological indices in male population

\begin{tabular}{|c|c|c|c|c|c|c|}
\hline Variables & Non SMDM & SMDM & & PI & $\mathbf{P 2}$ & P3 \\
\hline & & J 0 & J 100 & & & \\
\hline & Male (57) & Male (82) & Male (7I) & & & \\
\hline Age (month) & $119.28 \pm 24.42$ & $105.43 \pm 20.98$ & $104.93 \pm 20.36$ & 0.0005 & 0.0005 & 0.88 \\
\hline Height (cm) & $132.98 \pm 10.53$ & $132.05 \pm 10.97$ & $|32.4| \pm|| .27$ & 0.62 & 0.77 & 0.84 \\
\hline Weight (kg) & $28.83 \pm 6.88$ & $28.42 \pm 8.41$ & $29.43 \pm 8.81$ & 0.76 & 0.67 & 0.47 \\
\hline Body Mass Index $\left(\mathrm{kg} / \mathrm{m}^{2}\right)$ & $16.08 \pm 1.95$ & $15.97 \pm 2.66$ & $16.46 \pm 2.79$ & 0.78 & 0.38 & 0.26 \\
\hline WAZ(SD) & $-0.27 \pm 1.17$ & $-0.09 \pm 1.25$ & $0.09 \pm 1.22$ & 0.52 & 0.2 & 0.44 \\
\hline $\mathrm{HAZ(SD)}$ & $-0.65 \pm 1.23$ & $0.11 \pm 1.13$ & $-0.05 \pm 1.14$ & 0.0002 & 0.0053 & 0.36 \\
\hline $\mathrm{BAZ}(\mathrm{SD})$ & $-0.38 \pm 0.94$ & $-0.34 \pm 1.39$ & $0.01 \pm 1.16$ & 0.86 & 0.03 & 0.08 \\
\hline Family rate & $7.47 \pm 3.48$ & $6.80 \pm 1.65$ & $6.89 \pm 1.64$ & 0.27 & 0.34 & 0.82 \\
\hline 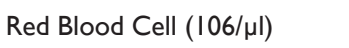 & $4.25 \pm 0.29$ & $4.44 \pm 0.46$ & $4.44 \pm 0.09$ & 0.0088 & $<0.0001$ & 0.05 \\
\hline Hemoglobin (g/dl) & $11.87 \pm 1.12$ & $11.99 \pm 1.38$ & $12.02 \pm 0.32$ & 0.57 & 0.31 & 0.85 \\
\hline Hematocrit (\%) & $36.67 \pm 3.14$ & $38.05 \pm 2.22$ & $38.21 \pm 2.19$ & 0.031 & 0.015 & 0.65 \\
\hline Mean CorpuscularVolume (fl) & $84.02 \pm 4.15$ & $71.62 \pm 7.34$ & $87.7 I \pm 2.57$ & $<0.000$ I & $<0.0001$ & $<0.0001$ \\
\hline $\mathrm{MHC}(\mathrm{pg})$ & $27.77 \pm 1.92$ & $27.26 \pm 1.98$ & $28.68 \pm 1.36$ & 0.13 & 0.0026 & $<0.0001$ \\
\hline $\mathrm{MCHC}(\mathrm{g} / \mathrm{dl})$ & $32.45 \pm 1.72$ & $32.25 \pm 3.44$ & $32.50 \pm 1.35$ & 0.32 & 0.78 & 0.35 \\
\hline 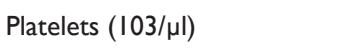 & $240.87 \pm 26.17$ & $289.24 \pm 73.65$ & $246.85 \pm 30.77$ & $<0.000$ I & 0.24 & $<0.0001$ \\
\hline White Blood Cell $(/ \mu \mathrm{l})$ & $6100 \pm 890$ & $4970 \pm 180$ & $4370 \pm 580$ & $<0.000$ I & $<0.000$ I & 0.008 \\
\hline Polynuclear Neutrophilis $(/ \mu \mathrm{l})$ & $3419.61 \pm 745.08$ & $1777.5 \pm 1355$ & $2373.6 \pm 399.3$ & $<0.000$ I & $<0.0001$ & 0.0005 \\
\hline 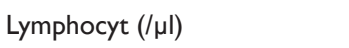 & $2425.61 \pm 468.54$ & $2754.20 \pm|| 3 \mid$ & $1773.4 \pm 1349$ & 0.041 & $<0.000$ I & $<0.0001$ \\
\hline Monocyt $(/ \mu \mathrm{l})$ & $232.43 \pm 91.26$ & $230.31 \pm 194.29$ & $209.7 \pm 87.27$ & 0.002 & 0.15 & $<0.0001$ \\
\hline
\end{tabular}

SMDM, school midday meal; RBC, red blood cells; MCV, mean corpuscular volume; WBC, white blood cell; MHC, mean hemoglobin concentration; MCHC, mean corpuscular hemoglobin concentration; BMI, body mass index;WAZ, weight for age $Z$ score; HAZ, height for age $Z$ score; BAZ, body mass index for age $Z$ score; J0, first survey; JI00, second survey; PI, comparison between Non SMDM receiving group and SMDM receiving group at J0 in male; P2, comparison between Non SMDM receiving group and SMDM receiving group at $\mathrm{J} 100$ in male; P3, comparison between SMDM receiving group at J0 and SMDM receiving group at $\mathrm{J} 100$ in male; SD, standard deviation

For body mass index for age $\mathrm{z}$ score mean (BAZ), target group (SMDM) had an elevated mean value as compared to control group (SMDM) with a significant difference between SMDM J100 $(0.01 \pm 1.16 \mathrm{SD})$ and Non SMDM $(-0.38 \pm 0.94 \mathrm{SD})(\mathrm{p}=0.03)$. The mean value of $\mathrm{RBC}$ (red blood cells) was $4.44 \pm 0.46 \times 106 / \mu 1$ in SMDM group against $4.25 \pm 0.29 \times 106 / \mu 1$ in Non SMDM group $(\mathrm{p}<0.05)$. The analysis of platelets mean count showed that SMDM male at J0 $(289.24 \pm 73.65 \times 103 / \mu 1)$ had the highest mean as compared to Non $\operatorname{SMDM}(240.87 \pm 26.17 \times 103 / \mu 1)$.

For the mean value WBC (White blood cells), Non SMDM male had the highest value $(6100 \pm 890 / \mu 1)$. According to our findings, SMDM group presented the highest mean value of lymphocytes $(2754.20 \pm 1131 / \mu 1)$ comparatively to Non SMDM group ( $<<0.005)$. The mean value of monocyte was normal conforming to reference $(218.37 \pm 101.2 / \mu 1)$.
According to Table 4, the mean age of female in SMDM group (103.08 \pm 19.18 month) was statistically lower than female's from Non SMDM group $(110.40 \pm 25.67$ month; $p<0.05)$. Concerning the mean value of Red Blood Cell (RBC), we noticed that the mean value of $\mathrm{RBC}$ was $4.56 \pm 0.45 \times 106 / \mu 1$ at $\mathrm{J} 0$ and at $4.46 \pm 0.15 \times 106 / \mu \mathrm{l}$ at $\mathrm{J} 100$ in SMDM group with a statistically difference in comparison with Non-SMDM $(4.24 \pm 0.29 \times 106 / \mu 1, \mathrm{p}<0.0001)$. The mean value of hemoglobin was $12.33 \pm 0.94 \mathrm{~g} / \mathrm{dl}$ and $12.13 \pm 0.64 \mathrm{~g} / \mathrm{dl}$ respectively at $\mathrm{J} 0$ and $\mathrm{J} 100$ in SMDM group against $11.90 \pm 0.98 \mathrm{~g} / \mathrm{dl}$ in Non SMDM group with a statistically difference $(\mathrm{p}=0.02)$.

Concerning platelets count, the mean value was higher at J0 $(279.93 \pm 69.23 \times 103 / \mu l)$ than platelets count at J100 $(238.20 \pm 37.04$ $\mathrm{x} 103 / \mu 1)$ in SMDM female. But, those values were higher than those in Non SMDM female $(238 \pm 22.96 \times 103 / \mu l)$ with significant value $(\mathrm{p}<0.0001)$. Concerning the mean value of White Blood Cell 
(WBC) count, female belonging to Non SMDM group showed the highest count of WBC with $6460 \pm 820 / \mu 1$ with statistically significant difference $(\mathrm{P}<0.0001)$ as compared to SMDM female respectively at $\mathrm{J} 0$ and $\mathrm{J} 100(5130 \pm 1390 / \mu 1 ; 4380 \pm 740 / \mu 1)($ Table 4).

The finding mentioned in the table 5, showed a statistically difference between male $\left(15.97 \pm 2.66 \mathrm{~kg} / \mathrm{m}^{2}\right)$ and female $(16.81 \pm 2.81$ $\mathrm{kg} / \mathrm{m}^{2}$ ) among SMDM receiving group at J0 concerning BMI (Body mass index) mean value in favor of female $(p<0.0001)$. The mean value of Weight for Age $\mathrm{Z}$ score was $0.44 \pm 1.45 \mathrm{SD}$ for female and $-0.27 \pm 1.77$ SD for male $(\mathrm{p}=0.02)$. Concerning the value of Height for Age $\mathrm{Z}$ score (HAZ), female presented higher value than the male in Non SMDM group and SMDM group with significant difference $(0.16 \pm 1.59$ SD vs $0.37 \pm 0.99 \mathrm{SD}, \mathrm{P}<0.05)$.

Table 4 Means values of anthropometrical and hematological indices in female population

\begin{tabular}{|c|c|c|c|c|c|c|}
\hline Variables & Non SMDM & SMDM & & $\mathbf{P I}$ & P2 & P3 \\
\hline & & J 0 & J 100 & & & \\
\hline & Female (76) & Female (63) & Female (59) & & & \\
\hline Age (month) & I I $0.40 \pm 25.67$ & $103.08 \pm 19.13$ & $102.92 \pm 18.78$ & 0.0005 & 0.0005 & 0.88 \\
\hline Height (cm) & $|34.2| \pm \mid 2.32$ & $|3| .73 \pm|| .27$ & $|33.4| \pm|| .33$ & 0.23 & 0.7 & 0.41 \\
\hline Weight (kg) & $30.50 \pm 8.48$ & $29.86 \pm 9.33$ & $31.17 \pm 9.98$ & 0.5 & 0.9 & 0.46 \\
\hline BMI $\left(\mathrm{kg} / \mathrm{m}^{2}\right)$ & $16.64 \pm 2.64$ & $16.81 \pm 2.90$ & $|7.08 \pm 3.0|$ & 0.72 & 0.53 & 0.61 \\
\hline WAZ(SD) & $0.44 \pm 1.45$ & $0.20 \pm 1.10$ & $0.18 \pm 1.06$ & 0.43 & 0.31 & 0.34 \\
\hline $\mathrm{HAZ}(\mathrm{SD})$ & $0.16 \pm 1.59$ & $0.25 \pm 1.02$ & $0.37 \pm 0.99$ & 0.51 & 0.18 & 0.41 \\
\hline $\mathrm{BAZ}(\mathrm{SD})$ & $-0.09 \pm 1.26$ & $0.14 \pm 1.10$ & $0.2 \mathrm{I} \pm \mathrm{I} .07$ & 0.39 & 0.24 & 0.76 \\
\hline Family rate & $7.17 \pm 2.34$ & $7.03 \pm 1.57$ & $7.16 \pm 1.60$ & 0.54 & 0.68 & 0.89 \\
\hline 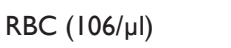 & $4.24 \pm 0.29$ & $4.56 \pm 0.45$ & $4.46 \pm 0.15$ & $<0.0001$ & $<0.0001$ & 0.05 \\
\hline Hemoglobin(g/dl) & $11.90 \pm 0.98$ & $12.33 \pm 0.94$ & $12.13 \pm 0.64$ & 0.02 & 0.34 & 0.16 \\
\hline Hematocrit (\%) & $36.56 \pm 2.89$ & $38.12 \pm 1.96$ & $38.28 \pm 8.30$ & 0.008 & 0.003 & 0.39 \\
\hline MCV (fl) & $83.8 \pm 3.95$ & $71.70 \pm 7.22$ & $87.68 \pm 2.14$ & $<0.000 \mathrm{I}$ & $<0.0001$ & $<0.0001$ \\
\hline $\mathrm{MHC}(\mathrm{pg})$ & $27.59 \pm 1.80$ & $27.30 \pm 1.88$ & $29 \pm 1.31$ & 0.47 & $<0.0001$ & $<0.0001$ \\
\hline $\mathrm{MCHC}(\mathrm{g} / \mathrm{dl})$ & $32.54 \pm 1.92$ & $32.26 \pm 1.44$ & $32.49 \pm 1.35$ & 0.31 & 0.87 & 0.43 \\
\hline Platelets $(103 / \mu \mathrm{l})$ & $238 \pm 22.96$ & $279.93 \pm 69.23$ & $238.20 \pm 37.04$ & $<0.0001$ & 0.22 & $<0.0001$ \\
\hline WBC $(/ \mu \mathrm{l})$ & $6460 \pm 820$ & $5130 \pm 139$ & $4380 \pm 740$ & $<0.000$ I & $<0.0001$ & 0.0082 \\
\hline P. Neutrophils $(/ \mu \mathrm{l})$ & $3651.67 \pm 612.35$ & $|86| .36 \pm|| 32$ & $2353.4 \pm 434.9$ & $<0.0001$ & $<0.0001$ & $<0.0001$ \\
\hline Lymphocytes $(/ \mu \mathrm{l})$ & $2538 . I I \pm 4|9.7|$ & $2848.69 \pm 924.7$ & $1817.4 \pm 402.9$ & 0.06 & $<0.0001$ & $<0.0001$ \\
\hline Monocytes $(/ \mu \mathrm{l})$ & $251.77 \pm 102.92$ & $316.25 \pm 164.6$ & $218.37 \pm 101.2$ & 0.08 & 0.08 & 0.97 \\
\hline
\end{tabular}

BMI, body mass index; WAZ, weight for age Z score; HAZ, height for age; BAZ, body mass index for age; RBC, red blood cell; Hb, hemoglobin; MCV, mean corpuscular volume; $\mathrm{MCHC}$, mean corpuscular hemoglobin concentration; $\mathrm{MCH}$, mean hemoglobin concentration; WBC, white blood cell; $\mathrm{PN}$, polynuclear neutrophils; SMDM, school midday meal receiving; J0, first survey; JI00, second survey; SD, standard deviation

Table 5 Means values of anthropometrical and hematological indices in the study population

\begin{tabular}{|c|c|c|c|c|c|c|c|c|c|}
\hline \multirow[t]{3}{*}{ Variables } & \multirow[t]{2}{*}{$\begin{array}{l}\text { Non SMDM } \\
\text { (133) }\end{array}$} & \multicolumn{3}{|c|}{ SMDM } & & & \multirow[t]{2}{*}{ PI } & \multirow[t]{2}{*}{ P2 } & \multirow[t]{2}{*}{ P3 } \\
\hline & & & J 0 (I45) & & J $100(130)$ & & & & \\
\hline & Male (57) & Female (76) & Male (82) & Female (63) & Male (7I) & Female (59) & & & \\
\hline Age (mois) & $119.28 \pm 24.42$ & $110.40 \pm 25.67$ & $105.43 \pm 20.98$ & $103.08 \pm 19.13$ & $104.93 \pm 20.36$ & $102.92 \pm 18.78$ & 0.08 & 0.35 & 0.41 \\
\hline Height (cm) & $132.98 \pm 10.53$ & $|34.2| \pm \mid 2.32$ & $132.05 \pm 10.97$ & $|3| .73 \pm|| .27$ & $|32.4| \pm|| .27$ & $|33.4| \pm|| .33$ & 0.42 & 0.72 & 0.77 \\
\hline Weight (kg) & $28.83 \pm 6.88$ & $30.50 \pm 8.48$ & $28.42 \pm 8.4 I$ & $29.86 \pm 9.33$ & $29.43 \pm 8.81$ & $31.17 \pm 9.98$ & 0.33 & 0.48 & 0.36 \\
\hline BMI $\left(\mathrm{kg} / \mathrm{m}^{2}\right)$ & $16.08 \pm 1.95$ & $16.64 \pm 2.64$ & $15.97 \pm 2.66$ & $16.81 \pm 2.90$ & $16.46 \pm 2.79$ & $|7.08 \pm 3.0|$ & 0.29 & $<0.001$ & 0.26 \\
\hline WAZ(SD) & $-0.27 \pm 1.17$ & $0.44 \pm 1.45$ & $-0.09 \pm 1.25$ & $0.20 \pm 1.10$ & $0.09 \pm 1.22$ & $0.18 \pm 1.06$ & 0.02 & 0.1 & 0.48 \\
\hline HAZ(SD) & $-0.65 \pm 1.23$ & $0.16 \pm 1.59$ & $0.11 \pm 1.13$ & $0.25 \pm 1.02$ & $-0.05 \pm 1.14$ & $0.37 \pm 0.99$ & 0.001 & 0.68 & 0.03 \\
\hline $\mathrm{BAZ}(\mathrm{SD})$ & $-0.38 \pm 0.94$ & $-0.09 \pm 1.26$ & $-0.34 \pm 1.39$ & $0.14 \pm 1.10$ & $0.01 \pm 1.16$ & $0.21 \pm 1.07$ & 0.02 & 0.0095 & 0.04 \\
\hline Family rate & $7.47 \pm 3.48$ & $7.17 \pm 2.34$ & $6.80 \pm 1.65$ & $7.03 \pm 1.57$ & $6.89 \pm 1.64$ & $7.16 \pm 1.60$ & 0.93 & 0.45 & 0.27 \\
\hline
\end{tabular}




\begin{tabular}{|c|c|c|c|c|c|c|c|c|c|}
\hline $\operatorname{RBC}(106 / 1)$ & $4.25 \pm 0.29$ & $4.24 \pm 0.29$ & $4.44 \pm 0.46$ & $4.56 \pm 0.45$ & $4.44 \pm 0.09$ & $4.46 \pm 0.15$ & 0.76 & 0.03 & 0.4 \\
\hline $\begin{array}{l}\text { Hemoglobin } \\
(\mathrm{g} / \mathrm{dl})\end{array}$ & $11.87 \pm 1.12$ & $11.90 \pm 0.98$ & $11.99 \pm 1.38$ & $12.33 \pm 0.94$ & $12.02 \pm 0.32$ & $12.13 \pm 0.64$ & 0.79 & 0.02 & 0.24 \\
\hline $\begin{array}{l}\text { Hematocrit } \\
\text { (\%) }\end{array}$ & $36.67 \pm 3.14$ & $36.56 \pm 2.89$ & $38.05 \pm 2.22$ & $38.12 \pm 1.96$ & $38.21 \pm 2.19$ & $38.28 \pm 8.30$ & 0.98 & 0.66 & 0.94 \\
\hline MCV (fl.) & $84.02 \pm 4.15$ & $83.8 \pm 3.95$ & $71.62 \pm 7.34$ & $71.70 \pm 7.22$ & $87.7 I \pm 2.57$ & $87.68 \pm 2.14$ & $<0.001$ & 0.7 & 0.64 \\
\hline $\mathrm{MHC}(\mathrm{pg})$ & $27.77 \pm 1.92$ & $27.59 \pm 1.80$ & $27.36 \pm 1.98$ & $27.30 \pm 1.88$ & $28.68 \pm 1.36$ & $29 \pm 1.31$ & 0.4 & 0.89 & 0.15 \\
\hline $\mathrm{MCHC}(\mathrm{g} / \mathrm{dl})$ & $32.44 \pm 1.42$ & $32.53 \pm 1.35$ & $32.47 \pm 1.35$ & $32.34 \pm 1.32$ & $32.36 \pm 1.44$ & $32.59 \pm 1.35$ & 0.31 & 0.87 & 0.43 \\
\hline $\begin{array}{l}\text { Platelets } \\
(103 / \mu l)\end{array}$ & $240.87 \pm 26.17$ & $238 \pm 22.96$ & $289.24 \pm 73.65$ & $279.93 \pm 69.23$ & $246.85 \pm 30.77$ & $238.20 \pm 37.04$ & 0.73 & 0.77 & 0.25 \\
\hline WBC $(/ \mu \mathrm{l})$ & $6100 \pm 890$ & $6460 \pm 820$ & $4970 \pm 180$ & $5130 \pm 139$ & $4370 \pm 580$ & $4380 \pm 740$ & 0.04 & 0.27 & 0.85 \\
\hline $\mathrm{PN}(/ \mu \mathrm{l})$ & $34|9.6| \pm 745.08$ & $3651.67 \pm 612.35$ & $1777.5 \pm 1355$ & $|86| .36 \pm|| 32$ & $2373.6 \pm 399.3$ & $2353.4 \pm 434.9$ & 0.1 & 0.32 & 0.81 \\
\hline $\begin{array}{l}\text { Lymphocytes } \\
(/ \mu \mathrm{l})\end{array}$ & $2425.6 I \pm 468.54$ & $2538.1 I \pm 4|9.7|$ & $2754.20 \pm|| 3 \mid$ & $2848.69 \pm 924.7$ & 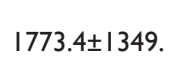 & $1817.4 \pm 402.9$ & 0.13 & 0.19 & 0.45 \\
\hline $\begin{array}{l}\text { Monocytes } \\
(/ \mu l)\end{array}$ & $232.43 \pm 91.26$ & $251.77 \pm 102.92$ & $230.31 \pm 194.29$ & $316.25 \pm 164.6$ & $209.7 \pm 87.27$ & $218.37 \pm 101.2$ & 0.35 & 0.86 & 0.66 \\
\hline
\end{tabular}

BMI, body mass index;WAZ, weight for age $Z$ score; HAZ, height for age; $B A Z$, body mass index for age; RBC, red blood cell; MCV, mean corpuscular volume; $\mathrm{MCHC}$, mean corpuscular hemoglobin concentration; $\mathrm{MCH}$, mean hemoglobin concentration;WBC, white blood cell; PN, polynuclear neutrophils; Lymph, lymphocyte; SMDM, school midday meal receiving; PI, comparison between male and female in Non SMDM receiving group; P2, comparison between male and female in SMDM receiving group at J0; P3, comparison between male and female in SMDM group at J100; J0, first survey; J100, second survey; SD, standard deviation

In what concern Body Mass Index for Age (BAZ), the female had the highest mean value within Non SMDM as compared to SMDM group $(p<0.05)$. Children from SMDM group at J0 especially female presented higher mean value of Red Blood Cell (4.56 \pm 0.45 x106/ $\mu \mathrm{l})$ and Hemoglobin $(12.33 \mathrm{~g} / \mathrm{dl})$ in relation to male belonging to the same group with respectively the mean value $(4.44 \pm 0.46 \times 106 / \mu 1$ and $11.99 \mathrm{~g} / \mathrm{dl} ; \mathrm{p}=0.03 ; \mathrm{p}=0.02$ ). The mean value of WBC in female with $6460 \pm 820 / \mu 1$ was higher than the one that male presented $(6100 \pm 890 /$ $\mu 1)$ with a statistically difference $(\mathrm{p}=0.04)$ among children from Non SMDM group (Table 5). Those mean values were respectively lower for male and female in SMDM group at J0 $(4970 \pm 1800 / \mu 1 ; 5130 \pm 1.39 /$ $\mu \mathrm{l})$ and $\mathrm{J} 100(4370 \pm 580 / \mu \mathrm{l} ; 4380 \pm 740 / \mu 1)$. No statistically difference between male and female was found $(\mathrm{p}>0.05)$.

\section{Hemtological parameters and nutritional status in study population}

Table 6, established a relationship between under nourished and normally nourished children. From the analysis of the Table 6, the result showed that undernourished pupils had lower hemoglobin level than normally nourished children without any statistically difference $(p>0.05)$. Concerning the mean value of White Blood Cells, undernourished children had higher value than normal one with statistically difference $(\mathrm{p}=0.01)$. Table 7 showed different proportion of nutritional status. According to ours findings 6.36\% among SMDM children at the first survey (J0) aged 5-9 years suffered from under nutrition $\left(\mathrm{p}^{2}=0.01\right)$. However, at the second visit $(\mathrm{J} 100)$, none child suffered from underweight. Concerning stunting, except the percentage of $2.86 \%$ against $2.56 \%$ in SMDM group among $10-14$ range, a statistical difference was observed between Non SMDM and SMDM group $(\mathrm{p}<0.05)$. Children aged from 10-14 years were more stunted than children from 5-9 years old $(\mathrm{p}<0.05)$.

Furthermore, children under 10 years old were more affected by microcytic anemia in the Non SMDM group with a proportion of $40.79 \%$ in comparison to children from SMDM group $(22.79 \%$; $9.89 \%)$ belonging to the same age group at J0, J100 ( $\mathrm{p}^{1}=0.02$; $\mathrm{p}^{2}=0.0005$ ). within SMDM group, we observed $22.72 \%$ of children were suffered from anemia at $\mathrm{J} 0$ and $9.89 \%$ at $\mathrm{J} 100(\mathrm{p}=0.02)$. No significant difference was observed in children with 5-9 years old in relation to children above 10 years.

Concerning thrombopenia, we observed a statistically difference between children under 10 years and children old than 10 in SMDM group at J0 and J100 (Table 7). A proportion of 5.71\% in SMDM receiving group more than years 10 olds at $\mathrm{J} 0$ presented Neutropenia and none case of neutropenia was observed in Non SMDM group with significant difference $(\mathrm{p}=0.004)$. Concerning lymphopenia, it was observed among SMDM group aged from 10-14 with a percentage of $2.86 \%$ compared to Non SMDM group $(\mathrm{p}=0.04)$.

Table 8 presents the proportions of different nutritional indices. According to our findings overweight was more frequent in all the different study groups with respectively $11.28 \%$ in Non SMDM group, $11.03 \%$ in SMDM group at $\mathrm{J} 0$ and $10.76 \%$ at $\mathrm{J} 100$ with none statistically difference $(\mathrm{p}>0.05)$. Concerning the percentage of underweight, $5.26 \%$ of children belonging to Non SMDM group were concerned, $6.20 \%$ in SMDM group at $\mathrm{J} 0$ and $0.76 \%$ at the second survey with statistically difference $(\mathrm{p}=0.02)$. However $6.77 \%$ of children in Non SMDM group was significantly more stunted as compared to SMDM group with $0.68 \%$ and $0.76 \%$ respectively at J0 and $\mathrm{J} 100\left(\mathrm{p}^{1}=0.01\right)$. We noticed that anemia was significantly higher among Non SMDM group with $37.59 \%$ versus $21.37 \%$ at the first survey in SMDM group and $11.53 \%$ at J100. No significant difference was observed within the SMDM group (21.37\% versus $11.53 \%)$. None child in Non SMDM group presented thrombopenia against $3.44 \%$ in SMDM group at J 0 with significant difference $(\mathrm{p}=0.02)$.

The analysis of Table 9 revealed different kind of malnutrition and haematological indices. Concerning underweight, male from SMDM group at J0 were more affected with the prevalence of $9.75 \%$ against $1.75 \%$ in Non SMDM group with a statistically difference $\left(\mathrm{p}^{1}<0.005\right)$. But at J100, that prevalence fell down from $9.75 \%$ to $1.41 \%$ in SMDM group with statistically difference as compared to male in Non SMDM and SMDM group $\left(\mathrm{p}^{5}<0.05\right)$. The comparison between sexes showed those males were more underweighted in SMDM than female group. 
But in Non SMDM group, female were more affected than male $(\mathrm{p}<0.05)$. Concerning Stunting, children from Non SMDM group were more stunted than SMDM group $(8.77 \%)$ with a statistically significant difference $\left(\mathrm{p}^{1<0.005)}\right.$. No significant difference was observed between male and female $(\mathrm{p}>0.05)$.

Table 6 Mean value of hematological parameters between undernourished normally nourished children

\begin{tabular}{|c|c|c|c|c|c|c|c|c|c|}
\hline \multirow[t]{3}{*}{ Variables } & \multicolumn{2}{|l|}{ Non SMDM } & \multicolumn{4}{|l|}{ SMDM } & \multirow[t]{3}{*}{ P I } & \multirow[t]{3}{*}{$\mathbf{P 2}$} & \multirow[t]{3}{*}{ P3 } \\
\hline & & & J 0 & & J 100 & & & & \\
\hline & $\begin{array}{l}\text { Under } \\
\text { nutrition }\end{array}$ & Normal & $\begin{array}{l}\text { Under } \\
\text { nutrition }\end{array}$ & Normal & $\begin{array}{l}\text { Under } \\
\text { nutrition }\end{array}$ & Normal & & & \\
\hline $\begin{array}{l}\text { RBC ( } \times 106 / \\
\mu l)\end{array}$ & $4.35 \pm 0.24$ & $4.23 \pm 0.29$ & $4.27 \pm 0.37$ & $4.50 \pm 0.48$ & $4.40 \pm 0.00$ & $4.43 \pm 0.12$ & 0.59 & 0.13 & 0.48 \\
\hline $\begin{array}{l}\text { Hemoglobin } \\
(\mathrm{g} / \mathrm{dl})\end{array}$ & $11.80 \pm 1.05$ & $|2.5| \pm 0.84$ & $11.8 \pm 1.16$ & $12.13 \pm 1.25$ & I I. $75 \pm 0.75$ & $12.03 \pm 0.58$ & 0.24 & 0.16 & 0.68 \\
\hline $\begin{array}{l}\text { Hematocrit } \\
(\%)\end{array}$ & $38.32 \pm 2.42$ & $36.36 \pm 3.03$ & $38.11 \pm 1.28$ & $38.14 \pm 2.19$ & $37.15 \pm 2.05$ & $38.15 \pm 2.24$ & 0.24 & 0.2 & 0.34 \\
\hline $\operatorname{MCV}(\mathrm{fl})$ & $85.85 \pm 3.93$ & $83.59 \pm 4.05$ & $73.33 \pm 1.28$ & $71.31 \pm 7.59$ & $87.75 \pm 0.25$ & $87.57 \pm 2.40$ & 0.0007 & 0.9 & 0.01 \\
\hline MHC (pg) & $28.47 \pm 1.52$ & $27.53 \pm 1.87$ & $28 \pm 1.63$ & $27.18 \pm 2.06$ & $29.2 \pm 0.2$ & $28.73 \pm 1.32$ & 0.52 & 0.48 & 0.34 \\
\hline $\mathrm{MCHC}(\mathrm{g} / \mathrm{dl})$ & $33.6 \pm 1.33$ & $32.39 \pm 1.74$ & $31.22 \pm 2.61$ & $32.11 \pm 3.66$ & $32.95 \pm 0.15$ & $32.44 \pm 1.36$ & 0.09 & 0.1 & 0.19 \\
\hline $\begin{array}{l}\text { Platelets( } 103 / \\
\mu \mathrm{l})\end{array}$ & $235.85 \pm 19.20$ & $238.86 \pm 25$ & $294 \pm 76.71$ & $283.15 \pm 74.13$ & $285.5 \pm 38.5$ & $241.13 \pm 33.74$ & 0.11 & 0.2 & 0.6 \\
\hline WBC $(/ \mu \mathrm{l})$ & $6000 \pm 920$ & $6330 \pm 850$ & $4100 \pm 172$ & $5060 \pm 168$ & $4800 \pm 0.0$ & $4370 \pm 660$ & $0.01 *$ & $0.02 *$ & 0.3 \\
\hline $\begin{array}{l}\text { P. Neutrophilis } \\
(/ \mu \mathrm{l})\end{array}$ & $3284.7 I \pm 632.88$ & $3568.40 \pm 682.37$ & $|579.22 \pm| 460$ & $1829.23 \pm 1304.43$ & $2527 \pm 113$ & $2365.03 \pm 416.76$ & 0.0007 & 0.11 & 0.06 \\
\hline $\begin{array}{l}\text { Lymphocytes } \\
(/ \mu \mathrm{l})\end{array}$ & $2500.7 I \pm 493.49$ & $2498.25 \pm 449.21$ & $2182.22 \pm 485.66$ & $2816.32 \pm 1074.95$ & $2036 \pm 164$ & $1787.49 \pm 366.23$ & 0.29 & 0.26 & 0.48 \\
\hline $\begin{array}{l}\text { Monocytes } \\
(/ \mu \mathrm{l})\end{array}$ & $|83.7| \pm 88.62$ & $245.37 \pm 99.96$ & $245 \pm 100.79$ & $317.57 \pm 190.57$ & $219 \pm 69$ & $214.86 \pm 96.56$ & 0.15 & 0.3 & 0.92 \\
\hline
\end{tabular}

SMDM, school midday meal; RBC, red blood cell; MCV, mean corpuscular volume; MCHC, mean corpuscular hemoglobin concentration; WBC, white blood cells; Poly, Polynuclear; J0, first survey; J100, second survey after 100 days; PI, comparison between undernourished in control group and canteen (J0) group; P2, comparison between undernourished in control group and canteen ( $\mathrm{I} 00$ ) group; $\mathrm{P} 3$, comparison between undernourished in canteen group at $\mathrm{J} 0$ and $\mathrm{JI} 00$; fl, femtolitre; pg, pictograms

Table 7 Proportions of nutritional indices according to age group

\begin{tabular}{|c|c|c|c|c|c|c|c|c|c|c|c|c|}
\hline \multirow[t]{2}{*}{ Variables } & \multirow[t]{2}{*}{$\begin{array}{l}\text { Non } \\
\text { SMDM } \\
(133)\end{array}$} & & \multicolumn{4}{|l|}{ SMDM } & \multirow[t]{2}{*}{ P I } & \multirow[t]{2}{*}{ P2 } & \multirow[t]{2}{*}{$\mathbf{P 3}$} & \multirow[t]{2}{*}{ P4 } & \multirow[t]{2}{*}{ P5 } & \multirow[t]{2}{*}{ P6 } \\
\hline & & & J0 (I45) & & $\begin{array}{l}J 100 \\
(130)\end{array}$ & & & & & & & \\
\hline \multirow[t]{2}{*}{ Year groups } & $5-9(76)$ & $\begin{array}{l}|0-| 4 \\
(57)\end{array}$ & $5-9(110)$ & $\begin{array}{l}10-14 \\
(35)\end{array}$ & $5-9(91)$ & $\begin{array}{l}10- \\
14(39)\end{array}$ & & & & & & \\
\hline & n \% & n \% & n \% & n \% & n \% & n \% & & & & & & \\
\hline Underweight & $3(3.94)$ & 4 (7.0I) & 7 (6.36) & $2(5.7 I)$ & $0(0)$ & I (2.56) & 0.44 & 0.01 & 0.002 & 0.71 & 0.14 & 0.26 \\
\hline Stunting & $2(2.63)^{*}$ & $\begin{array}{l}7 \\
(12.28)^{*}\end{array}$ & $0(0)^{*}$ & I $(2.86)^{*}$ & $0(0)$ & I (2.56) & 0.009 & 0.05 & 0.05 & 0.01 & 0.008 & 0.89 \\
\hline Overweight & 12 (I5.79) & $4(7.01)$ & II (I0) & $5(14.29)$ & $\begin{array}{l}10 \\
(10.99)\end{array}$ & $4(10.26)$ & 0.25 & 0.35 & 0.82 & 0.11 & 0.44 & 0.41 \\
\hline Obesity & 3 (3.94) & $2(3.50)$ & $5(4.55)$ & I (2.86) & $4(4.40)$ & $2(5.13)$ & 0.83 & 0.87 & 0.96 & 0.79 & 0.57 & 0.28 \\
\hline Anemia & 31 (40.79) & $\begin{array}{l}19 \\
(33.33)\end{array}$ & $25(22.72)$ & $6(17.64)$ & $9(9.89)$ & $6(15.38)$ & 0.02 & 0.0005 & 0.02 & 0.02 & 0.09 & 0.69 \\
\hline Thrombopenia & $0(0)$ & $0(0)$ & $2(1.82)^{*}$ & $3(8.57)^{*}$ & $0(0)^{*}$ & $2(5.13)^{*}$ & - & 0.11 & - & 0.0005 & 0.007 & 0.35 \\
\hline Leucopenia & I (I.3I) & I (I.75) & $3(2.73)$ & $0(0)$ & I (I.I0) & $0(0)$ & 0.47 & 0.89 & 0.39 & 0.11 & 0.11 & - \\
\hline Neutropenia & $2(2.63)$ & $0(0)$ & $4(3.64)$ & $2(5.7 I)$ & I (I.I0) & I (2.56) & 0.68 & 0.42 & 0.23 & 0.004 & 0.05 & 0.26 \\
\hline Lymphopenia & $2(2.63)$ & $0(0)$ & $3(2.73)$ & I (2.86) & I (I.I0) & $0(0)$ & 0.96 & 0.42 & 0.05 & 0.04 & - & 0.05 \\
\hline
\end{tabular}

SMDM, school midday meal; J0, first day of survey; J100, second survey after 100 days, PI, comparison of proportions between Non SMDM group and SMDM group aged 5-9 years at J0; P2, comparison of proportions between Non SMDM group and SMDM group aged 5-9 years at JI00; n, number; \%, percentage; P3, comparison of proportions within SMDM aged 5-9 years (J0 vs JI00); P4, comparison of proportions between Non SMDM group and SMDM group aged I0- I4 years at J0, P5, comparison of proportions between Non SMDM group and SMDM group aged I0-I4 years at JI00; P6, comparison of proportions within SMDM group aged I0-I4 years at JI00; (*), comparison proportion of 5-9 years against 10- I4 years in Non SMDM group and SMDM group level of significance ( $\mathrm{P}<0.05$ ) 
Table 8 Proportion of different parameters of nutritional status in the whole population

\begin{tabular}{|c|c|c|c|c|c|c|}
\hline Variables & Non SMDM (133) & SMDM & & P I & $\mathbf{P 2}$ & $\mathbf{P 3}$ \\
\hline & & $\mathrm{J} 0(145)$ & $\mathrm{J} 100(130)$ & & & \\
\hline & $\mathbf{n} \%$ & n \% & $\mathbf{n} \%$ & & & \\
\hline Underweight & $7(5.26)$ & $9(6.20)$ & I (0.76) & 0.78 & 0.05 & 0.02 \\
\hline Stunting & $9(6.77)$ & I (0.68) & I (0.76) & 0.01 & 0.01 & 0.94 \\
\hline Overweight & $15(11.28)$ & $16(11.03)$ & $14(10.76)$ & 0.95 & 0.91 & 0.95 \\
\hline Obesity & $5(3.76)$ & $6(4.13)$ & $5(3.84)$ & 0.89 & 0.97 & 0.91 \\
\hline Anemia & $50(37.59)$ & 31 (2I.37) & $15(11.53)$ & 0.03 & 0.0001 & 0.08 \\
\hline Thrombopenia & $0(0)$ & $5(3.44)$ & $2(1.54)$ & 0.02 & 0.14 & 0.38 \\
\hline Leucopenia & $2(1.50)$ & $3(2.07)$ & I (0.76) & 0.76 & 0.61 & 0.42 \\
\hline Neutropenia & $2(1.50)$ & $6(4.14)$ & $2(1.54)$ & 0.25 & 0.98 & 0.26 \\
\hline Lymphopenia & $2(1.50)$ & $4(2.73)$ & I (0.76.) & 0.54 & 0.61 & 0.27 \\
\hline
\end{tabular}

n, number; \%, percentage; J0, first survey, J100, second survey after 3 months; SMDM, school midday meal; PI, P value for comparison of proportion of Non SMDM group versus SMM group at J0; P2, p value for comparison of proportion of Non SMDM group versus SMDM group at JI00; P3, P value for comparison of proportion among SMM group (J0 versus J100); $<<0.05$, level of significance

Table 9 Proportion of nutritional indices according to gender

\begin{tabular}{|c|c|c|c|c|c|c|c|c|c|c|c|c|}
\hline \multirow[t]{4}{*}{ Variables } & \multicolumn{2}{|l|}{$\begin{array}{l}\text { Non } \\
\text { SMDM }\end{array}$} & \multicolumn{4}{|l|}{ SMDM } & \multirow[t]{2}{*}{$\mathbf{P I}$} & \multirow[t]{2}{*}{$\mathbf{P 2}$} & \multirow[t]{2}{*}{ P3 } & \multirow[t]{2}{*}{ P4 } & \multirow[t]{2}{*}{ P5 } & \multirow[t]{2}{*}{ P6 } \\
\hline & & & J 0 & & J 100 & & & & & & & \\
\hline & Male (57) & $\begin{array}{l}\text { Female } \\
(\mathbf{7 6})\end{array}$ & Male (82) & $\begin{array}{l}\text { Female } \\
(63)\end{array}$ & $\begin{array}{l}\text { Male } \\
(7 I)\end{array}$ & Female & 59) & & & & & \\
\hline & $n \%$ & $n \%$ & n \% & $n \%$ & n \% & $n \%$ & & & & & & \\
\hline Underweight & I $(\mathrm{I} .75)^{*}$ & $6(7.89)^{*}$ & $8(9.75)^{*}$ & I $(1.59)^{*}$ & I (I.4I) & $0(0)$ & 0.01 & 0.84 & 0.008 & 0.03 & 0.0009 & 0.13 \\
\hline Stunting & $5(8.77)$ & $4(5.26)$ & I (I.22) & $0(0)$ & I (I.4I) & $0(0)$ & 0.01 & 0.01 & 0.9 & 0.006 & 0.06 & - \\
\hline Overweight & $4(7.01)$ & II (I4.47) & 7 (8.54) & $9(14.29)$ & $\begin{array}{l}9 \\
(12.68)\end{array}$ & $\begin{array}{l}10 \\
(16.95)\end{array}$ & 0.69 & 0.19 & 0.36 & 0.97 & 0.65 & 0.63 \\
\hline Obesity & $2(3.50)$ & $3(3.94)$ & $3(3.67)$ & $3(4.76)$ & $2(2.82)$ & $3(5.08)$ & 0.94 & 0.78 & 0.73 & 0.78 & 0.7 & 0.91 \\
\hline Anemia & $21(36.64)$ & $29(38.15)$ & $23(28.05)^{*}$ & $8(12.70)^{*}$ & $\begin{array}{l}9 \\
(12.68)\end{array}$ & $\begin{array}{l}6 \\
(10.17)\end{array}$ & 0.28 & 0.0004 & 0.01 & 0.0002 & $5.56 e^{-5}$ & 0.59 \\
\hline Thrombopenia & $0(0)$ & $0(0)$ & $2(2.44)$ & $3(4.76)$ & $2(2.82)^{*}$ & $0(0)^{*}$ & 0.06 & 0.04 & 0.86 & 0.01 & - & 0.01 \\
\hline Leucopenia & $2(3.50)^{*}$ & $0(0)^{*}$ & $2(2.44)$ & I (I.59) & $0(0)$ & I(I.69) & 0.66 & 0.02 & 0.06 & 0.13 & 0.12 & 0.95 \\
\hline Neutropenia & $2(3.50)^{*}$ & $0(0)^{*}$ & $4(4.88)$ & $2(3.17)$ & I (I.4I) & I (I.69) & 0.63 & 0.33 & 0.15 & 0.03 & 0.12 & 0.49 \\
\hline Lymphopenia & $2(3.50)^{*}$ & $0(0)^{*}$ & $3(3.67)$ & I (I.59) & I (I.4I) & $0(0)$ & 0.94 & 0.33 & 0.3 & 0.13 & - & 0.13 \\
\hline
\end{tabular}

J0, first survey day 0; J100, second survey after 100 days; SMDM, school midday meal; $n$, number; \%, percentage; PI, comparison between male in Non SMDM and male in SMDM group at J0; P2, comparison between male in Non SMDM and male in SMDM group at JI00; P3, comparison between male in SMDM at J0 and male in SMDM group at J100; P4, comparison between female in Non SMDM and female in SMDM group at J0; P5, comparison between female in Non SMDM and female in SMDM group at JI00; P6, comparison between female in SMDM at J 0 and female in SMDM group at JI00 ( $<<0.05$ ); $(*)$, significant comparison between male and female in Non SMDM and SMDM group $(p<0.05)$

Concerning anemia, male in Non SMDM group with $36.64 \%$ were more affected than male in SMDM group at J100 with the prevalence of $12.68 \%(\mathrm{p}=0.0004)$. A significant difference was observed between male at $\mathrm{J} 0(28.05 \%)$ and female at $\mathrm{J} 100(12.68 \%)(\mathrm{p}=0.01)$. Female in Non SMDM group were more anemic with the prevalence of $38.15 \%$ than female at J0 and $\mathrm{J} 100$ respectively $12.70 \%$ and $10.17 \%$ with significant difference $(\mathrm{p}<0.05)$. In what concern thrombopenia, no child was affected in Non SMDM group, female in SMDM group were more affected at J0 with a statistical difference as compared to female at $\mathrm{J} 100(\mathrm{p}=0.01)$. No significant difference was found between SMDM group and Non SMDM receiving group concerning leucopenia, neutropenia and lymphopenia.

\section{Discussion}

The assessment of nutritional status is pivotal in the pediatric field for dealing with both healthy and sick children. This study concerning the nutritional status in relation to their haematological profile confirmed that malnutrition is not yet eradicated in our study population. The prevalence of underweight was 5.26\% in Non SMDM group against $6.77 \%$ at $\mathrm{J} 0$ and $0.76 \%$ at $\mathrm{J} 100$ in SMDM group. The prevalence of stunting was $6.77 \%$ in Non SMDM group, $0.68 \%$ and $0.76 \%$ respectively in SMDM group at $\mathrm{J} 0$ and $\mathrm{J} 100$. The prevalence of overweight was $11.28 \%$ in Non SMDM group; $11.03 \%$ and $10.76 \%$ at J0 and J100 in SMDM group. The prevalence of obesity was 3.76\% in Non SMDM group; $4.13 \%$ and $5.38 \%$ respectively at J0 and $\mathrm{J} 100$ 
in SMDM group. Anemia, with the prevalence of $37.59 \%$ in Non SMDM group and $21.37 \%$ at J0, $11.53 \%$ at $\mathrm{J} 100$ in SMDM group. While the proportion of protein-energy malnutrition was decreasing, we observed an increasing level of overweight/obesity reaching almost $11 \%$ of children in our study.

That prevalence was higher compared to the prevalence that we observed in a preview study in Abidjan with a prevalence of $8.94 \% .{ }^{24}$ That prevalence is lower than what is observed by authors in United States with the prevalence of $16 \%$ among children aged from 6-16 years old. ${ }^{25}$ Also we noticed low percent of under nutrition at second survey J100, in comparison to J0 and Non SMDM receiving group. ${ }^{24}$ That can be explained by the fact that children from target group (SMDM group) belonged to family that was well educated with good socio economic status. And those pupils comparatively to the control group enjoyed balanced diet at home and at school. That can explain why children receiving School Midday Meal were well nourished in comparison to Non-receiving School Midday Meal children. Our finds are similar to those of Sabely et al. ${ }^{26}$ in Egypt and in India. ${ }^{26,27}$ In their study, these authors found that school meal improved nutritional status of primary school children. In children from Non-receiving School Midday Meal, we found that stunting and underweight were higher as compared to SMDM receiving group. Both groups were significantly different in nutritional status, and percentage of anemia. ${ }^{28}$ The possible explanation for Non SMDM being the most affected by malnutrition may be attributed to various reasons such as poor socio economic conditions of parents, exposure to unhygienic environment with the lack of proper care and attention for adequate nutrition that is required during the growing year. ${ }^{29}$

Children male genre was suspect to suffer from malnutrition more than the female. Furthermore, children aged from 5-9 years were more malnourished than the elders (10-14 years). That result can be explained by the fact that girls grow up more quickly than boys. Concerning the age group, children from 5-9 years needs more nutrients to grow up and is very vulnerable to nutrients deficiencies. Also children from control group sometime didn't have a balanced diet at midday, so they cannot reach the adequate quantities of proteins and micronutrients such as vitamins and minerals recommended to their growth. ${ }^{30}$ As seen in our study, the difference in stature and weight between SMDM and Non SMDM group and an increased percentage of under nutrition/stunting in Non SMDM receiving group and overweight has been reported in India. ${ }^{31,32}$ The prevalence of under nutrition observed in this study particularly in control group can be also explained by the fact that most of the children belonged families with lower education level. Parental education had been identified in other population as a predictor of under-nutrition. Poorest population segments are the least educated that increases the gap between the richest and the poorest. ${ }^{33,34}$ However, the proportion of stunting and under nutrition found in our study population was lower than those reported by the previous authors. This low prevalence of under nutrition can be explained by fact that our study was carried out in residential area where most of parents have good social conditions, for socio-demographic factors correlates with nutritional status according to Mushtaq et al. ${ }^{35,36}$ When compared to the prevalence cutoff values of World Health Organization, the prevalence of stunted and wasted children in our study was under the critical category $(\leq 15 \%){ }^{37}$ Stunting is an indicator of chronic malnutrition during the first years of life.

Growth deficit tends to accumulate with age and particularly in boys, as observed in our study and in other studies of school children in developing countries.$^{38}$ Children from Non SMDM receiving group suffered more from malnutrition than those from SMDM receiving group. Our results are similar to the results observed by Bhargava et al. ${ }^{32}$ in India during their study. ${ }^{32}$ Contrary to our study, some authors observed that children who used to take the lunch in school canteen suffered more from malnutrition than children who used to have their lunch in street. ${ }^{28}$ In what concerning overweight or obesity, the rate is increasing reaching $11 \%$ in our study population that prevalence was higher than what observed with the proportion of $6.29 \%$ in Ouagadougou. ${ }^{38}$ Nevertheless this prevalence was lower than those observed in India with the prevalence of $40.8 \%{ }^{39}$ However a study conducted in Cote d'Ivoire by Lokrou and Nioblé, ${ }^{36}$ in 2008 among schoolchildren was higher than the prevalence in our study. During their study the authors found that the prevalence of overweight and obesity was $12.5 \%$ among the subjects of their study. ${ }^{36}$

Anemia was observed in both control and target group. But children from control group (Non SMDM) indicated higher rate of anemia with the proportion of $37.59 \%$ against $21,37 \%$ and $11.53 \%$ in target group (SMDM) respectively at J0 and J100 (Table 8).

This study also confirmed that anemia is common to protein energy malnutrition. That confirms that anemia is the most widespread malnutrition problem in schoolchildren in developing countries. ${ }^{40}$ Low mean value of hemoglobin, hematocrit and red blood cell observed in Non-SMDM receiving children as compared to SMDM receiving children in this study, were observed by Daboné et al. ${ }^{38}$ and Kokoré et al. ${ }^{41}$ during their study. ${ }^{38,41,42}$ These authors observed that children who received school lunch had better haematological profile than children who took lunch outside the school canteen. ${ }^{43}$ That could be explained by the fact that children from SMDM group had balanced and diversified diet with appropriated nutrients required for the growing and development of the students. In fact according to the recipes observed, the diet was balanced and varied with important nutrients (proteins, energy, lipid, and vitamins) intake in SMDM group. However, the high prevalence of anemia can be the fact iron deficiency which the main factor of anemia, but it is not the only one cause of anemia. Anemia can be the fact of infection, for infection plays a key role, notably malaria and hookworms in African schoolchildren. $^{38}$

The meals were cooked in a clean and healthy environment as school Canteen. Besides school canteen represents an adequate environment for a good nutrition and an opportunity to inculcate good feeding practices to the school children. So canteen is an important tool to provide nutritional education. ${ }^{44}$ In other hand, parent's education levels and activity play an important role concerning reducing malnutrition among children from SMDM group. In our study, we found that most of parents in this case, women benefited from good education and had good professional activity. Also most of them were civil servant or paid employee. A study conducted in Guatemala in 2007 demonstrated that children that lived in a family with important socio economic resources have better nutritional status. ${ }^{45}$

However, the current study didn't show significant differences between haematological parameters of malnourished children compared to normally nourished children among SMDM and Non SMDM groups. That can be explained by the fact that no case of severe malnutrition was observed in our study and malnutrition was mild to moderate. The prevalence of anemia in Non-SMDM receiving group was higher $(37.59 \%)$ as compared to children belonging to SMDM group (with the prevalence of $21.38 \%$ at J0 and $11.53 \%$ at 
J100). Our findings were lower in comparison to the result found by some authors in Ouagadougou (Burkina Faso) with the prevalence of $40.40 \%{ }^{38}$ Boys were more anemic than girls and according to age the children from 5-9 years old were more anemic than the elders. Our findings were similar to those observed in Burkina Faso. ${ }^{38}$

Hemoglobin, Hematocrit, Red Blood Cell indices were normal in SMDM children and Non SMDM children. That could be explained by the fact that in our study, all form of malnutrition was moderate, none case of severe malnutrition has been observed. Yet, a study leaded by authors in Nigeria, showed that haematological indices decrease in protein Energy Malnutrition. ${ }^{46}$

\section{According to these authors various factors contributed anemia such as}

a. Iron deficiency

b. Reduced Red cell production in adaptation to lean smaller body mass

c. Erythropoietin deficiency

d. Folic acid and vitamin B12 deficiency

e. Deficiency in trace element (Cooper and Zinc)

\section{f. Infections}

Iron deficiency is the most common trace element deficiency worldwide, affecting between $20 \%$ and $50 \%$ of the world population mainly infants, children and women of child bearing age. ${ }^{47,48}$ Severe acute malnutrition is always associated with increased severity of common infectious diseases and death among children with severe acute malnutrition is almost always as a result of infection such as malaria. ${ }^{21}$ Even if malnutrition is known to be a factor associated with anemia, particularly in vulnerable group living in low income countries, such case has not been observed in our study, for malnutrition was moderate in our study population. That can be the fact that all the children included in our study were in healthy state and no one complained to suffer from any illness. Significant elevation of white blood cell count of Non SMDM receiving group compared to SMDM receiving group was observed. But all those mean value were normal according to references values. ${ }^{37}$ Our findings were contrary to the results found by Patel et al. In their study, those authors observed statistically difference between SMDM group and non SMDM group..$^{28}$

Furthermore, an inadequate dietary intake leads to weight loss, lowered immunity and invasion by pathogens and malnutrition predisposes to infection, increases the severity and morality of infections. Also malnutrition and infection tended to occur in the same population with poor setting resources and poverty. ${ }^{49}$ In our study, we noticed that blood platelet count was normal they both SMDM group and Non SMDM group. No pathological difference was found between SMDM receiving children and Non SMDM receiving children. Contrary to our findings, some studies showed that blood platelets count significantly increased in malnourished children as compared to normally nourished children.

Others studies mentioned that platelet activation is not correlated with infection particularly malaria in which one, plasmodium can interact with different receptors on human platelet which shortened the life span and pathogens can induce removal of platelet from the circulation by stimulating their sequestration in organ or by triggering their clearance by phagocytosis, that can explain thrombocytopenia commonly associated with malaria. ${ }^{50}$

Others works conclude that platelet reactivity depends on the hemoglobin levels rather than the iron parameters with significant correlation between hemoglobin levels or serum iron and transferrin saturation on one hand and parameters of platelet aggregation on the other hand. ${ }^{8}$

\section{Conclusion}

The midday meal program was entitled towards providing nutritious diet to the school children with aim of at least covering $1 / 3$ of child's daily calorie requirements and half of daily protein requirement to reduce hunger, malnutrition and improve school attendance. At the end of this study, based in our findings, it appears that protein-energy malnutrition, overweight and anemia were still present among urban schoolchildren. However school children from Non SMDM group our control group were the most affected by under nutrition, stunting and, anemia. SMDM group in the study showed better nutritional status than healthy comparison group who belonged to Non SMDM children. We noticed that school midday program reduced the rate of underweight and stunting, but it seems to have no effect concerning overweight. Concerning anemia, children from Non SMDM receiving children were more anemic than the SMDM receiving group. Children from SMDM group had better nutritional status than the Non SMDM group at J0 and J100. After all this argument we can conclude that school feeding program had a positive impact on the hemoglobin rate but not on the white blood cells and platelet. Our study showed that balanced and healthy diet acts as a supplement to fight against malnutrition and iron deficiency which is the main cause of anemia.

Also because of simultaneous presence anemia, under nutrition and over nutrion among the same population showed that country is faced to the triple burden of malnutrition (protein-energy malnutrition, micronutrients deficiencies and overweight). School midday meal improve schoolchildren nutritional status. However appreciate the nutritional status by anthropometric and hemtological parameters is limited because anemia can be caused by diseases. Thus, there is urgent to reassess the SMDM program, in light of findings of similar studies and assess the biochemical indices such as albumin, prealbumin, vitamin $\mathrm{A}$ and $\mathrm{E}$ in those children in comparison to Non SMDM children.

\section{Acknowledgements}

The authors thank the children's parents, and teachers for their support. Profound appreciation is extended to the schoolchildren of the different school included in that study, we are deeply grateful to all administrative staff of the department of education of Cocody 1 in Abidjan district under the authority of Mrs Gougoue who allowed us to conduct that study. We thank all the academic and administrative staff of Laboratory of Physiology, Pharmacology and Phytotherapy in Nangui Abrogoua University (Abidjan).

\section{Author's contributions}

JKA was the main investigator for the study, designed the study, supervised data collection, analysis on the field and wrote the manuscript under the supervision of MNB. MNB advised on data collection and helped to write the manuscript. He advised on the design of the study and wrote the demand for department of education 
authority consent to conduct the study in the area. MNB reviewed the draft and made some changes. Supervised and emended the final form of the paper to be submitted. PAY was the main director and the designer of the study, overall project management, reviewing of manuscript, supervised the setting, read and approved the final manuscript.

\section{Conflict of interest}

The authors declare that they have no competing interests.

\section{Reference}

1. Nel E. Children's nutritional Needs and relatives in an emerging world. Ann Nutr Metab. 2014;64(2):5-6.

2. Noel WS. La dénutrition dans les pays en voies de développement, les aspects évolutifs. Annales de Nestlé (Fr). 2009;67:74-8.

3. Müller O, Krawinkel M. Malnutrition and health in developing countries. CMAJ. 2005;173(3):279-286.

4. Kinimo RY. Déterminants de la sous-alimentation des ménages en Côte d'Ivoire: cas des régions Centre et Centre Est. European Scientific Journal. 2013;9(14):207-228.

5. Nemer L, Gelband H, Jha P. Commission on Macroeconomics and Heath. The evidence base for intervention to reduce malnutrition in children under-fives and school children in low-middle income countries. CMH working paper No WG5:11. Geneva, Switzerland; World Health Organization. 2001.

6. Brabin BJ, Coulter JBS. Nutrition associated disease. In: Cook GC, Zumla M, editors. Manson's tropical diseases. London, UK; Sounders. 2003;561-80.

7. Müller O, Garenne M, Kouyaté B, et al. The association between energy protein malnutrition, malaria morbidity and all causes of mortality in West African children. Trop Med Int Health. 2003;8(6):507-511.

8. Basheir HM, Hamza KM. Haematological parameters of Malnourished Sudanese children under 5 years, Kartoun State-2011. Clinical Medicine Journal. 2015;1(4):152-156.

9. Yukie Higashiyama, Masaru Kubota, Satoko Oshima, et al. Assessment of Japanese healthy children's nutritional status using Waterlow classification. Health. 2012;4(11):1036-1040.

10. FAO. Deuxième conférence international sur la nutrition. Rome, 19-2 Novembre 2014. Note des coprésidentes sur les documents finaux de la Conférence. Italy: 2016; p. 1-16.

11. Best C, Neufingerl N, Van den Briel T, et al. The Nutritional status of school aged children: Why should we care? Food and Nutrition Bulletin. 2010;31(3):400-417.

12. Amruth M, Kumar S, Kulkarni AG, et al. A study on nutritional status and morbidity pattern among primary school children in Sullia town, South India. Indian Journal of Basic and Applied Medical Research. 2015;4(4):100-112.

13. Chandra RK, Kumari S. Nutrition and immunity: an overview. J Nutr. 1994;124 Suppl 8:1433S-1435S

14. Yapi HF, Yapo A, Yeo D, et al. Effet des malnutritions mineures et modérées sur les protéines immunitaires, inflammatoires et nutritionnelles chez l'enfant en Côte d'Ivoire. Mali Medical. 2009;4.

15. OMS. Comité d'experts sur l'appréciation médicale de l'état de nutrition. Série Rapport Technique 258. Geneva: Switzerland; World Health Organization. 1963; 74 p.
16. OMS. Utilisation et interprétation de l'anthropométrie: rapport d'un comité d'experts. série de rapports techniques 854. Genève, Switzerland; World Health Organization. 1995.

17. Radwan F. Les marqueurs biochimiques de la nutrition. Nutrition, Science, science en evolution. 2003. p. 15

18. Brunner S, Baré B, Smeltzer SC. Soins infirmiers en médecine et chirurgie. Canada, UK: De Boeck; 2011. 500 p.

19. 16 Recensement Général de la Population et de 1'Habitat 2014. Rapport d'execution et presentation des principaux resultats. 2014.

20. de Onis M, Onyango AW, Borghi E, et al. Development of a WHO growth reference for school-aged children and adolescents. Bull World Health Organ. 2007;85(9):660-667.

21. Jones KD, Berkley JA. Severe acute malnutrition and infection. Paediatr Int Child Health. 2014;34 Suppl 1:S1-S29.

22. Chutani AM. School lunch program in India: background, objectives and components. Asia Pac J Clin Nutr. 2012;21(1):151-154.

23. Bhagwat S, Sankar R, Sachdeva R. et al. Improving the nutrition quality of the school feeding program (Mid-Day Meal) in India through fortification: a case study. Asia Pac J Clin Nutr. 2014;23 Suppl 1:S12-S19.

24. Akpole JK, Bléyeré MN, Yapo PA. Low anthropometrics indices of malnutrition in children of school canteen located in Cocody (Abidjan/ Côte d'Ivoire). International Journal of Science and Healthcare Research. 2016;1(4):33-44

25. Farr SA, Yamada KA, Butterfield DA, et al. Obesity and hypertriglyceridemia lead to cognitive deficiency. Endocrinology. 2008;149(5):2628-2636.

26. Amirat Ali El-Sabely, Hanan MM Tork,Yousria El-Sayid Hussien. Comparative study of nutritional status and dietary habits of children from public and private primary school in Zagazig city, Egypt. IOSSR Journal of Nursing and Health Science. 2013;3(1):47-52.

27. Palanisamy Navaneethan,Thiagarajan Kalaivani, Chandrasekaran Rajasekaran, et al. Nutritional status of children in rural India: a case study from Tamil Nadu, first in the world to initiate the Mid-Day Meal scheme. Health. 2011;3(10):647-655

28. Patel PP, Patel PA, Chylonkar SA, et al. Effect of Mid-day meal on nutritional status of adolescents: A cross sectional study from Gujarat. Indian Journal of Child Health. 2016;3(3):203-207.

29. Bradley RH, Corwyn RF. Socioeconomic status and child development Annu Rev Psychol. 2002;53:371-399.

30. Shruti Kantawala, Uma lyer, Swati Dhruti, et al. Perceptions of municipalities' school teacher of urban Vododara on strengths and weaknesses of midday meal programme: voices from the ground. Journal of community Nutrition \& health. 2013;2(2):26-31.

31. Alim F, Khalil S, Mirz I, et al. Impact of mid-day meal scheme on the nutritional status and academic achievement of school children in Aligarh city. Indian Journal Sciences Research. 2012;3(2):85-90.

32. Bhargava M, Kandpal SD, Aggarwal P, et al. A comparative study of midday meal beneficiaries and private school attendees. Indian Journal of Community Health. 2014;26 Suppl S2:223-227.

33. Semba RD, de Pee S, Sun K, et al. Effect of parental formal education on risk of child stunting in Indonesia and Bangladesh: a cross- sectional study. Lancet. 2008;371(9609):322-328.

34. Moestue H, Huttly S. Adult education and child nutrition: the role of family and community. J Epidemiol Community Health. 2008;62(2):153-159. 
35. Mushtaq MU, Gull S, Khurshid U, et al. Prevalence and sociodemographic correlates of stunting and thinness among Pakistani primary school children. BMC Public Health. 2011;11:790.

36. Lokrou A, Nioblé G. Prévalence du surpoids et de l'obésité en milieu scolaire en Côte d'Ivoire. Med Malad Metab. 2008;2(3):303-304.

37. WHO. Nutrition Landscape Information System, country profile indicators, interpretation guide. Geneva, Switzerland; World Health Organization. 2010: 38 p.

38. Daboné C, Delisle HF, Receveur O. Poor nutritional status of schoolchildren in urban and peri-urban areas of Ouagadougou (Burkina Faso). Nutr J. 2011;10:34.

39. Sudhagandhi B, Sivapatham S, William WE, et al. Prevalence of anaemia in the school children of Kattankulathur, Tamil Nadu, India. Int J Nutr Pharmacol Neurol Dis. 2011;1(2):184-188.

40. Anozie AO, Agha NC, Nwachukwu NN, et al. Influence of malnutrition on biochemical parameters of primary School-Aged children Ohaji Egbema local Government Area of IMO State Nigeria. J Nutr Food Sci. 2013;3(4):1-6.

41. Kokoré BA, Bléyéré MN, Ehilé EE. et al. L’anémie nutritionnelle chez les écoliers de trois communes du district d'Abidjan en Côte d'Ivoire. Antropo. 2013;29:49-56.

42. Kokoré BA, Bléyéré MN, Kouakou LK, et al. Haematological status and anaemia prevalence among children aged 5 to 11 years in school canteens in Abidjan (Côte d'Ivoire). Int J Cur Res Rev. 2013;5(13):37-51.
43. WHO. Humanitarian Charter and Minimum Standards in Humanitarian Response. Minimum Standards in Food Security and Nutrition. Geneva, Switzerland; The Sphere Project. 2011. 344 p.

44. Fréderike Mensink, Saskia Antoinette Schwinghammer, Astrid Smeets The Healthy School Canteen Programme: A Promising Intervention to Make the School Food Environment Healthier. J Environ Public Health. 2012;2012:8.

45. Groeneveld IF, Solomons NW, Doak CM. Nutritional status of urban school children of high and low socio economic status in Quetzaltengo, Guatemala. Rev Panam Salud Publica. 2007;22(3):167-177.

46. Soka AA, Saka MJ, Ojuawo A. Hematological profile in children with PEM in North Central Nigeria. Global Journal of Medical Research. 2012;12(4):1-7.

47. Katona P, Katona-Apte J. The interaction between nutrition and infection. Clin Infect Dis. 2008;46(10):1582-1588.

48. Speth C, Loffler J, Krappmann S, et al. Platelets as immune cells in infectious diseases. Future Microbiol. 2013;8(11):1431-1451.

49. Kokoré BA, Bléyéré MN, Kamagaté S, et al. Iron deficiency and iron deficiency anaemia in children canteens in Abidjan, Côte d'Ivoire. Saudi J Biomed Res. 2016;1(3):64-71.

50. OMS. Norme de croissance de l'enfant séries des rapports techniques 854, département de nutrition. World Health Organization. Genève: Switzerland; 2016 